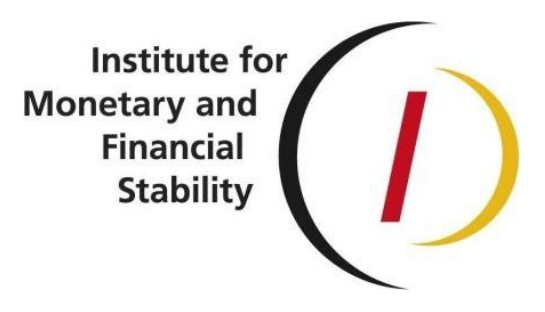

ATHANASIOS ORPHANIDES

What Happened in Cyprus? The Economic Consequences of the Last Communist Government in Europe

Institute for Monetary and Financial Stability

GoETHE UNIVERSITY FRANKFURT AM MAIN

Working PAPER SerIES No. 79 (2014) 
This Working Paper is issued under the auspices of the Institute for Monetary and Financial Stability (IMFS). Any opinions expressed here are those of the author(s) and not those of the IMFS. Research disseminated by the IMFS may include views on policy, but the IMFS itself takes no institutional policy positions.

The Institute for Monetary and Financial Stability aims at raising public awareness of the importance of monetary and financial stability. Its main objective is the implementation of the "Project Monetary And Financial Stability" that is supported by the Foundation of Monetary and Financial Stability. The foundation was established on January 1, 2002 by federal law. Its endowment funds come from the sale of 1 DM gold coins in 2001 that were issued at the occasion of the euro cash introduction in memory of the D-Mark.

The IMFS Working Papers often represent preliminary or incomplete work, circulated to encourage discussion and comment. Citation and use of such a paper should take account of its provisional character.

\section{Institute for Monetary and Financial Stability}

Goethe University Frankfurt

House of Finance

Grüneburgplatz 1

D-60323 Frankfurt am Main

www.imfs-frankfurt.de I info@imfs-frankfurt.de 


\title{
What Happened in Cyprus? The Economic Consequences of the Last Communist Government in Europe
}

\author{
Athanasios Orphanides* \\ MIT
}

May 2014

\begin{abstract}
This paper reviews developments in the Cypriot economy following the introduction of the euro on 1 January 2008 and leading to the economic collapse of the island five years later. The main cause of the collapse is identified with the election of a communist government in February 2008, within two months of the introduction of the euro, and its subsequent choices for action and inaction on economic policy matters. The government allowed a rapid deterioration of public finances, and despite repeated warnings, damaged the country's creditworthiness and lost market access in May 2011. The destruction of the island's largest power station in July 2011 subsequently threw the economy into recession. Together with the intensification of the euro area crisis in the summer and fall of 2011, these events weakened the banking system which was vulnerable due to its exposure in Greece. Rather than deal with its fiscal crisis, the government secured a loan from the Russian government that allowed it to postpone action until after the February 2013 election. Rather than protect the banking system, losses were imposed on banks and a campaign against them was coordinated and used as a platform by the communist party for the February 2013 election. The strategy succeeded in delaying resolution of the crisis and avoiding short-term political cost for the communist party before the election, but also in precipitating a catastrophe right after the election.
\end{abstract}

KEywords: Cyprus, euro area, crisis, sovereign debt, populism.

JEL Classification: D72, E32, E65, F34, H12, H63

*This paper is based on the author's presentation at the 2nd Scientific Conference of the Tassos Papadopoulos Studies Center on Cyprus: Five Years in the Eurozone, Nicosia, 17-18 May 2013. I would like to thank Lorenzo Bini Smaghi, Charles Calomiris, Benjamin Friedman, Charles Goodhart, Otmar Issing, Simon Johnson, Julio Rotemberg, Simon van Norden and participants of presentations at LSE and MIT for helpful discussions and comments. Correspondence: MIT Sloan School of Management, E62-481, 100 Main Street, Cambridge, MA 02142. Tel.: +1-617-324-4051. E-mail: athanasios.orphanides@mit.edu. 


\section{Introduction}

The introduction of the euro in Cyprus on 1 January 2008 was cause for celebration on the island. The joy was well deserved. ${ }^{1}$ The event culminated decades of efforts to bring Cyprus closer to the core of Europe. As with so many other decisions relating to the euro, the reasons Cyprus sought to join were not economic but primarily political in nature. Isolated geographically from the rest of Europe, Cyprus had faced numerous challenges as a small independent state in a strategic location. About a third of the island continued to be under occupation following the 1974 invasion by Turkey that also displaced a large fraction of the population of the island. The decisions to join the European Union in 2004 as well as the euro area in 2008 were made to strengthen the political standing of the island and to promote greater stability.

When Cyprus joined the euro the economy was in good condition. Successive governments had worked hard to create a growth model that employed the highly educated workforce in offering financial services. Cyprus had developed into a regional financial center. ${ }^{2}$

Fiscal finances were in good order. The government ended 2007 with a $3.3 \%$ surplus and a debt-to-GDP ratio of $60 \%$ that was projected to fall below $50 \%$ by the end of 2008. (European Commission, 2008, p. 81.) The country had a solid banking system. Funding was stable and deposits exceeded loans. Despite a real estate overheating that was experienced after Cyprus was admitted into the European Union in 2004, and unlike the UK, Ireland and Spain, risks were relatively contained by tight loan-to-value ratios. By the time it joined the euro area, Cyprus had already in place liquidity regulations and macro-prudential measures whose significance was only later recognized by the international central banking community. ${ }^{3}$

\footnotetext{
${ }^{1}$ The photograph in Figure 1 shows President Tassos Papadopoulos holding new euro notes withdrawn from an ATM at the Ministry of Finance at the celebration that took place there right after midnight on 1 January 2008.

${ }^{2} \mathrm{~A}$ historical overview of the economy of the island and its development is collected in the volume edited by Orphanides and Syrichas (2012).

${ }^{3}$ Prudential liquidity requirements were tightened with the entry to the euro area by introducing a stock liquidity ratio and loan-to-value restrictions before the entry cooled the overheated real-estate market. (Central Bank of Cyprus, 2010.)
} 
Five years later, the economy was in shambles. For nearly two years the government lacked access to capital markets. By March 2013, euro deposits in Cyprus became unequal to euro deposits elsewhere. Depositors faced restrictions on the use of their funds. Economic activity had ground to a halt and the economy was in a free fall.

How could this happen? Could anyone see this coming? Figure 2 shows credit default swap (CDS) data for the five euro area member states that have requested assistance from the troika so far-Greece, Ireland, Portugal, Spain and Cyprus. The figure shows daily data that reflect the premium someone would need to pay to insure against a default on government bonds. The last observation shown is 28 February 2013. This figure confirms that Cyprus (in the copper colored line), had been in a crisis. But this figure obscures a crucial element that made Cyprus unique: A government refusing to act.

Figure 3 illustrates what made Cyprus unique. The figure shows the same data but with a twist. For each country, a triangle shows the date when the eurogroup received a request for help from its government. For Greece, for example, this was on 23 April 2010. For each country, the last observation shown, denoted with a solid circle, is the date in which its MoU was finalized. For Greece, this last date is 2 May 2010. As can be seen, in each case, when a government ran into difficulties, with the CDS spreads reaching or exceeding about 600 basis points, it asked for help. And in each case within three weeks or so, a program was agreed, a Memorandum of Understanding (MoU) signed, and the government started its implementation.

With one exception: Cyprus. The Cypriot government had already run into problems in May 2011, almost two years before the collapse. But unlike everyone else, the Cypriot government refused to follow the rules. More than a full year had passed before the Cypriot government was forced to ask for help, on the same day that Spain asked for assistance. Cyprus was also unique in that its government refused to finalize an MoU after it asked for assistance. In contrast, as shown on the chart, Spain completed its agreement on 20 July 2012, about three weeks after it had asked 
for help.

The government's inaction had severe economic consequences. As can be seen on Figure 4, unemployment reached historic highs. This was the first time in the history of the Republic when unemployment reached double-digit levels during peace time. Worse still, by February 2013, one out of every three young adults was unemployed. The government had set in motion all the ingredients needed for creating a lost generation.

Following a career at the Federal Reserve, I was asked by President Tassos Papadopoulos to serve as Governor of the Central Bank of Cyprus and help introduce the euro on the island. I served a five-year term from 3 May 2007 to 2 May 2012 and continued to follow events after the end of my term. This paper reviews developments in Cyprus following the introduction of the euro and leading to the island's economic collapse in March 2013.

\section{What made Cyprus unique?}

What happened? What made Cyprus so unique and led to its economic collapse? In February 2008, just two months after Cyprus joined the euro area, there were presidential elections. In these elections the public voted the leader of the communist party as President of the Republic. ${ }^{4}$ The island has a presidential system where the President of the Republic has absolute control on the executive branch for a fixed term of five years with virtually no additional checks and balances. ${ }^{5}$ By winning the presidency, the communist party effectively gained absolute control of policy-making for the first time in the history of the island, for five years. Cyprus became the first and only member state of the European Union whose government was controlled by

\footnotetext{
${ }^{4}$ The communist party AKEL was founded in 1926 as the Communist Party of Cyprus which, according to the party's history (as presented on its website), "introduced to Cyprus the ideas and ideology of socialism" and "laid down the foundations for the class-based workers movement connecting it from the beginning with the Marxist-Leninist outlook."

${ }^{5}$ This reflects the legacy of the political stalemate on the island. The 1960 constitution provided better checks and balances as the executive branch was to be governed by a President and a VicePresident. However, it stipulated that the Vice-President should be a member of the Turkish-Cypriot community and the position has been vacant since 1963, when the Turkish-Cypriot community withdrew from the government.
} 
a communist party.

In 2008 the public did not foresee the catastrophe this could bring. At that time, the economy was doing so well that voters focused on the political problem of the island. The communist party had convinced the majority of the population that if it won the election it could solve the long-standing political problem that has divided the island since 1974 .

The communist government started overspending immediately. When the global financial crisis started in 2008 a mild recession hit the island and growth stagnated in 2009. The environment of stagnating growth coupled with continued increases in spending started creating doubts about the sustainability of the country's fiscal affairs.

With the crisis hitting Greece in 2010, Cyprus became more vulnerable as a result of the interconnectedness and exposure of the Greek and Cypriot banking sectors. Ensuring the credibility of the government became even more important. However, the government chose to ignore the problem and by May 2011 it lost access to financial markets, thus creating additional stress to the economy and its banking system.

The destruction of the island's largest power station in July 2011 subsequently threw the economy into recession. Together with the intensification of the euro area crisis in the summer and fall of 2011, these events weakened the banking system which was vulnerable due to its exposure in Greece.

Financial markets continued to raise red flags, posing a choice for the government: Fix the problem, regain credibility, restore fiscal sustainability. Or make the problem worse. With the February 2013 election approaching, the communist party dug in and focused on how to minimize short-term political costs. Rather than deal with its fiscal crisis, the government secured a bilateral loan from the Russian government that allowed it to circumvent its inability to access markets and postpone meaningful action until after the February 2013 election. In the meantime, it started an assault on the banking system to deflect attention and ran the election on a "bash-the-banks" platform. 
By the time the five-year communist administration of Cyprus had ended, the economic model of the country was destroyed.

\section{$3 \quad$ The spending spree}

The spending spree that started the imbalance in 2008 can be easily seen by comparing two figures. Figure 4 shows the evolution of real GDP in Cyprus. Growth had averaged around 4 percent per year before the crisis. Starting in 2007, the chart shows a 4 percent growth path (the blue dashed line) and a zero percent growth path (the red dashed line). As can be seen, in the five years that followed, real GDP remained about flat.

By contrast, as shown in Figure 5, real government expenditures accelerated after 2007. This stopped only when the government ran out of money in 2011 and could no longer keep up. In the meantime, the government refused to correct imbalances and ignored long-term projections. The preferred argument provided was that the current debt-to-GDP ratio remained below the average for the euro area suggesting considerable room for more spending and bigger deficits.

A first priority for the government was the rapid increase in social spending. Social spending could be easily exploited politically. By highlighting increases in social spending, the communist party could demonstrate that in contrast to previous administrations, it "cared" for the people. The large increases were presented as a huge achievement. In presenting the budget for 2011 on 16 September 2010, for example, Finance Minister Stavrakis highlighted that social spending had increased by $15 \%, 11 \%$ and $12 \%$ in 2008, 2009 and 2010, respectively "in total over $42 \%$ during [President] Christofias' term." (Ministry of Finance, 2010, p. 4, author translation).

To be sure, increasing social spending need not be problematic. The government could have ensured that resources for the desired expenditures were available, for example by curtailing other expenditures or by proper targeting of social spending. But these options were not popular and would be inconsistent with the political claims 
of the communist party. ${ }^{6}$ Overall spending had to rise. The hallmark of populism was at play. As long as money could be borrowed, budget constraints could be ignored.

The government raised current and future expenditures by hiring a large number of new government employees. In the three years following 2007, total employment in the central government increased by $9 \%$. Wages in the broader public sector also increased at a fast pace, despite the economic slowdown that was punishing the private sector in the economy.

In addition, the government significantly increased commitments for future expenditures by raising pensions and other retirement benefits without taking steps to ensure their funding. Some raises were through automatic cost of living adjustments that the government had refused to adjust following entry into the euro area as was warranted. This created a further disconnect between the economy's productivity and public expenditures.

The unfunded future liabilities of the government generated serious sustainability concerns about long-term finances which were noted as early as 2009. In its 2009 Ageing Report, the European Commission identified Cyprus as one of the countries facing the largest projected increase in expenditures to meet ageing-related obligations that the government had already made (European Commission, 2009). While minor adjustments were made, as a result of the pressure generated by the criticism from Brussels, the government refused to tackle the problem in a credible fashion. By the 2012 Ageing Report, Cyprus was identified as one of the high risk countries in the EU (European Commission, 2012a). Annual public pension expenditures over the years 2010-60 were projected to increase by 8.4 percentage points of GDP (against an average of just 1.4 for the EU). ${ }^{7}$

\footnotetext{
${ }^{6}$ The government even rejected targeting an Easter "gift" to retirees, a program initiated soon after it took office. Checks were distributed to all pensioners, regardless of income or wealth, despite numerous calls that the program should be targeted.

${ }^{7}$ The Parliament raised employer and employee contributions to pension funds. Rather than invest them to prepare for the projected future payments, the government diverted the proceeds and used them to finance other current expenditures. Intra-governmental borrowing, which is not reported in headline debt statistics, increased by about 20 percentage points of GDP in the four years following 2007.
} 
The Commission incorporated the accumulated fiscal deterioration in its 2012 Fiscal Sustainability Report. In its overall assessment, Cyprus was singled out as the only member state of the European Union where the Commission's indicators pointed to a "high risk" for long-term sustainability. The Commission noted, in particular that "the long-term cost of ageing is very high" (European Commission 2012b, p. 9).

\section{Warnings ignored}

Couldn't someone explain to the government the consequences of ever increasing government expenditures? Couldn't someone highlight the added risks stemming from the global crisis? In fact there were many attempts to warn regarding the risks and the consequences of the government's failure to tackle the accumulated imbalances. Warnings came from official institutions like the IMF, the European Commission and the ECB. Warnings came from local institutions, including the Central Bank and the technocrats at the Ministry of Finance. Warnings came from political parties (with the exception of the communist party) and others. None were successful. Solutions required short-term political costs that the communist government refused to accept.

The Central Bank of Cyprus raised concerns to the government as early as 2009. In a letter addressed to the President on 1 December 2009, on the occasion of discussions regarding the 2010 budget, the Central Bank noted that the deteriorating fiscal balance posed long-term risks for the Republic. ${ }^{8}$ After reviewing the state of the economy and fiscal projections, the Central Bank noted (author translation):

"The situation is critical. It is imperative that a medium-term strategic plan for fiscal correction be developed. ... the sooner the appropriate measures are taken, the milder the consequences will be."

Concerns intensified during 2010 due to the further deterioration of fiscal finances in the context of the sovereign crisis in the euro area. The President of the Republic, of course, was intimately aware of the deterioration in the euro area as he represented

\footnotetext{
${ }^{8}$ The correspondence became public after a parliamentary committee requested it in 2012 .
} 
Cyprus in key meetings of the European Council where the most important strategic decisions for handling the crisis were being made. ${ }^{9}$ In light of the worsening situation in Greece, the large size of the banking system and the connectedness to Greece implied greater vulnerability to fiscal missteps and increased risks.

On 18 May 2010, the Central Bank presented another warning to the President (author translation):

"The recent dramatic events in Greece have intensified existing concerns about Cyprus ... the collapse in Greece started as a fiscal crisis, put in danger the banking sector and subsequently the whole economy. This has put fiscal problems elsewhere under the microscope. ...

Cyprus has not yet attracted close scrutiny because of its small size. In my view, this is just a matter of time ... for a number of reasons such as ... the worsening fiscal deficits and high level of public and private debt ... the very large size of the banking sector compared to GDP ...

I stress that unless there is a change in direction with meaningful fiscal consolidation, primarily on the expenditure side, the consequences for the Cypriot economy will be catastrophic."

Despite the warning that without a change in direction the consequences for the Cypriot economy would be catastrophic, the government opted not to change course.

Before the end of the year, on 15 December 2010, the presidential palace received another warning, this time from the European Central Bank. The letter (co-signed by the President of the ECB and the Governor of the Central Bank of Cyprus) was emphatic and stressed that in light of the large size of the Cypriot banking system, the country risked getting caught in a negative feedback loop between the financial sector and public debt. In the context of the euro area crisis that could be disastrous for the country:

"In light of recent market concerns about public debt sustainability, it is

\footnotetext{
${ }^{9}$ See Orphanides (forthcoming) for a historical review of some critical meetings of the EU Heads of State or Government and their implications for the crisis.
} 
more important than ever that every country benefiting from the common currency takes prompt and effective steps to ensure that its public finances are on a sound footing. Experience has shown that waiting for market pressures before acting exacerbates tensions and ultimately increases the needed adjustment size. Although Cyprus' sovereign debt market has a limited size, significant concerns exist. These concerns are particularly relevant in view of the large size of the Cypriot banking system, which may produce negative feedback loops between the financial sector and public debt. ... The challenges faced by the Cypriot economy require prompt corrective action. We are confident that the Government will rapidly take the needed measures."

Despite the urgent call for "prompt corrective action," the government continued to refuse to take any action.

Not heeding the ECB warning was particularly costly for Cyprus. Through its actions, the ECB had demonstrated its willingness to provide support and diffuse stress situations. During 2010, it had started purchasing Greek, Irish, and Portuguese bonds as part of its Securities Markets Programme (SMP). During 2011, following a similar exchange of letters with the heads of governments of Spain and Italy, and subsequent to the adoption of measures by these governments, the ECB started purchases of Italian and Spanish debt.

Cyprus was unique. It had the government that chose to dismiss all warnings. In contrast to the heads of governments of Spain and Italy, the Cypriot leader did not even respond to the ECB warning. Unsurprisingly, the ECB made no purchases of Cypriot bonds as it could not justify supporting the government bond market of a government unwilling to behave responsibly.

\section{$5 \quad$ Losing market access}

The failure of the government to correct its widening fiscal problems and the deterioration in Greece attracted attention to Cyprus in 2011. The sovereign was downgraded. 
Instead of taking consolidation measures to improve its long-term outlook, the government imposed a levy on banks to raise more revenue and continue spending. The bank levy, imposed in March 2011, proved to be the opening salvo in what was to follow. The global crisis was already pressuring banks. The situation in Greece, where the Cypriot banking system had exposure had deteriorated. Cypriot banks had been successfully raising additional capital to defend against rising risks. In this environment, and despite objections from the Central Bank, the government chose to add to these pressures by imposing an additional levy. ${ }^{10}$

Technocrats at the Ministry of Finance were alarmed by the deteriorating situation of the country's fiscal and competitiveness performance. On 29 March 2011, a confidential memorandum presenting an analysis of the state of the Cypriot economy that was addressed to the Permanent Secretary of the Ministry concluded: ${ }^{11}$

"The main conclusion is that the immediate implementation of a bold and credible economic program is required that would ensure the restoration of fiscal balance, the strengthening of competitiveness and the improvement of the general image of Cyprus in conjunction with the risks that emanate from the large size and exposure of our banking system in Greece. Unless this is done, Cyprus will suffer from instability and a deterioration of its macroeconomic indicators, with adverse implications regarding the implementation of the government's program and the achievement of its economic and social objectives." (Ministry of Finance, 2011, p. 3, author translation)

It is not known if Christos Patsalides, the Permanent Secretary to whom this memorandum was addressed, conveyed the dire consequences of the government's inaction to the Minister of Finance and the President of the Republic. What is known is that while the situation kept deteriorating, the Ministry of Finance officially denied

\footnotetext{
${ }^{10}$ The Central Bank had been asked its opinion by a parliamentary committee. It opposed a levy that would be directed to the general budget and urged the adoption of a levy to be used to build a financial stability fund that could serve as an additional capital buffer for the banking system.

${ }^{11}$ The whole quoted paragraph was underlined for emphasis. The word "immediate" was underlined and in bold letters.
} 
it, even after this memorandum appeared in the press on 4 May 2011. Minister Stavrakis dismissed the findings and denied that the analysis and fiscal projections in the memorandum reflected the baseline assessment of the ministry's staff. Regardless, the publication brought to light that according to the ministry's own staff, the deficit targets for the year that had been communicated in public were unrealistic. Two days later, on 6 May 2011, the ministry announced that the deficit for the first quarter of 2011 was much larger than expected. But the government continued to deny the existence of any problems, damaging its credibility.

There was a reason for the denials. The Ministry of Finance was trying to avoid disclosing the deterioration of the country's finances prior to the parliamentary elections that were scheduled to take place later in May. In addition, for many months, the ministry had been postponing needed long-term bond issuance. The maturity of the debt was significantly and dangerously shifted from long-term financing to shortterm financing. It was later disclosed that the Ministry of Finance had even asked a rating agency to postpone downgrading the sovereign until after the parliamentary election. The rating agency, Fitch, obliged. ${ }^{12}$

The government's plan was successful. Despite the severe deterioration in the country's prospects, the communist party gained one seat in the Parliament on 22 May 2011. However, the country was to pay a huge price. In the process, the government had lost control of its financing. On 26 May 2011, the ministry announced a shift to domestic borrowing, admitting that it could no longer access international bond markets. A few days later, on 3 June 2011, the ministry announced a huge gap in public pensions, thus also admitting the unsustainability of the government's pension plans.

Anyone with access to market data could see the tsunami coming. The Central Bank had been providing this information to all stakeholders, including government officials and members of parliament. An example is reproduced in Figure 6 which

\footnotetext{
${ }^{12}$ The Finance Minister, Charilaos Stavrakis, took credit for convincing Fitch in a book he authored after he left the ministry and confirmed the event at a hearing of the Investigation Committee on the Economy (Pantelides, 2013).
} 
shows daily data on 10-year government bonds until early May 2011. Markets had treated Cyprus similarly to Italy and Spain until the end of 2010. The government's refusal to take action with the 2011 budget put Cyprus in a worse condition. Portugal was the only member state in the euro area giving cover to Cyprus. By the beginning of 2011, it was clear that if Portugal was forced to seek help, Cyprus could be next. Action was urgently needed. But the focus of the communist party was on winning an extra seat in Parliament which precluded taking any actions that would indicate that the government had gone off track.

Figure 7 shows an update of Figure 6 with data extended to the end of May 2011. The jump of the copper-colored line following the 22 May election indicates that the loss of market access was immediately evident in the data, even though the government had tried to obscure it by announcing its intention to shift its borrowing to domestic sources.

By mid-June, yields were as high as the levels for Greece, Ireland and Portugal when they were in the process of contacting the IMF and European Commission to ask for financial assistance. The chart in Figure 8 is reproduced from a figure that was attached to yet another warning letter sent by the Central Bank to the President of the Republic on June 17. As with all previous warnings, this too was ignored.

\section{The explosive summer}

The summer of 2011 presented an explosive mix for Cyprus. The government had lost access to markets in May. There was a very unfortunate Iran-Syria arms-related incident in early July. And the euro area crisis intensified.

On 11 July 2011 an explosion near the village of Mari destroyed the power station producing more than half of the island's power supply. It was triggered by the high heat to which about 100 containers of ammunition were exposed for over two years. The containers were part of a shipment of arms from Iran to Syria that violated an international embargo. The shipment was intercepted in January 2009 in Cypriot territorial waters after a tip from the United States and the containers were stored 
on a hill in a naval base overlooking the power station. Two summers later they were still there, until the explosion on 11 July 2011.

The incident had a tremendous economic cost and political repercussions. Over half of the island's electricity supply was lost. The island had to endure rolling power outages. Prior to the explosion, the economy was recovering from the mild recession associated with the global financial crisis in late 2008 and 2009. Real GDP had registered positive growth in every quarter during 2010 and during the first half of 2011. In the aftermath of the July explosion, GDP declined sharply, registering a 4.5\% decline (seasonally adjusted annual rate) in the third quarter of 2011 and further smaller declines in subsequent quarters.

The unemployment rate, which at $7.6 \%$ was already at a historic high in June 2011, increased rapidly following the explosion. It rose by more than two percentage points by the end of the year and continued to rise rapidly to double digits during 2012 and beyond (Figure 3). To comprehend the extent of the economic dislocation, it could be noted that with the exception of the 1974-76 period that reflected the war and subsequent economic adjustment, the average annual unemployment rate had exceeded $5 \%$ only once in the history of the Republic. Outside the war-related period, the unemployment rate had never reached $6 \%$ during any previous administration, from 1960 to 2008.

In light of the government having lost market access before the explosion, it had become imperative that action be taken immediately to restore confidence and avoid a collapse. On 18 July 2011, in yet another warning to the Presidential Palace, the Central Bank noted that the economy was in a critical condition comparable to that of 1974 , alluding to the catastrophe that took place a generation earlier.

"Accounting for all, the unfavorable global environment, the difficulties in securing international financing, the further adverse economic consequences from recent events, I believe that the economy is in a critical condition comparable to that in 1974. Consequently, to avoid the worst, including being forced to a support mechanism with all this implies for 
the economy and our national issue, it is imperative to adopt and quickly implement measures ..." (author translation).

Action was imperative. Unfortunately, once again, political considerations dominated. Action was not forthcoming. Action would have involved politically unpopular measures. The warning letter was leaked to the press and the Central Bank was attacked for being alarmist. The communist party and advisers of the government argued against the actions that would have resolved the crisis. $^{13}$

The explosion also created political instability and paralyzed the government. Large demonstrations were organized calling for the resignation of the government. Responding to the public outcry, the government appointed a respected lawyer, Polys Polyviou, as independent investigator to investigate the causes of the explosion and identify responsibilities for the disaster. The investigation was completed in September 2011. It concluded that the government was at fault, and that the President himself was personally responsible. The investigation concluded that the risks of storing the ammunition in the sun had been identified and the government, including the President personally, had been informed but the decision had been taken not to take any action. The findings suggested that the President had ignored warnings that the dangerous cargo should be destroyed hoping that it could be returned later on so that the good relations that had been established with Syria's President Assad would not be compromised (Figure 9). ${ }^{14}$ The conclusion was a damning indictment of the government in general and the President of the Republic in particular.

"The key in this case is that the President of the Republic failed to arrange or even take elementary measures for the security of the citizens of the Republic of Cyprus, and especially soldiers and firefighters.

\footnotetext{
${ }^{13}$ For example, Demetriades (2011) commented that the Central Bank's effort to warn the government of the consequences of inaction was a baseless, misguided, unfortunate and provocative political intervention.

${ }^{14}$ According to the evidence presented, on 31 August 2009, President Christofias personally assured President Assad during an official visit to Damascus that "the government had decided to keep and store the cargo until it could be returned to Syria or Iran." (Polyviou, 2011, p. 167, author translation.)
} 
I stress, clarify, and conclude that I do not simply refer to institutional and political responsibility, which always exists. In this case, I find that the President of the Republic bears severe personal responsibility for the tragic event and its consequences." (Polyviou, 2011, p. 612, author translation.)

The communist party immediately dismissed the conclusions of the investigation and rallied around its government and the President. Despite public outcry and calls for the resignation of the President and for his criminal prosecution, the calls were ignored. The constitution of the Republic protected the President with immunity and did not require either popular support or parliamentary support for staying in power until the following presidential elections in 2013.

These developments made it even harder for the government to consider any action that would have added further short-term political cost. The economic and political disaster associated with the explosion raised the political stakes for the communist party. It became critical to find a target that could be used to deflect the public's attention away from the actions and inaction of the communist government and their devastating consequences for the country. That target would be the banks.

\section{The state of the banks}

By the summer of 2011, the country was at serious risk. But what about its banking system? Certainly, the banking system of any country facing persistent fiscal imbalances, a loss of confidence in the sovereign and a worsening recession sooner or later would face difficulties. Preconditions for effective banking supervision, according to the core principles of the Basel Committee, were no longer met. ${ }^{15}$ But what was the state of the Cypriot banking system in July 2011? The answer can be obtained by looking at the results of a stress test by the European Banking Authority (EBA) that coincidentally were published during the same week as the explosion, on 15 July.

\footnotetext{
${ }^{15}$ The first and most important precondition is "sound and sustainable macroeconomic policies." According to the Committee: "sound macroeconomic policies (mainly fiscal and monetary policies) are the foundation of a stable financial system. Without sound policies, imbalances such as high government borrowing and spending, and an excessive shortage or supply of liquidity, may arise and affect the stability of the financial system." (Basel Committee on Banking Supervision, 2012.)
} 
The two largest Cypriot banks participated in that European-wide exercise and both passed. The system was under pressure, but banks had been systematically raising capital to defend against risks and could weather even possible haircuts to Greek debt that were then under discussion. In addition, the Central Bank had asked the two large banks to strengthen their capital positions in anticipation of tighter capital requirements that included a surcharge for large institutions. ${ }^{16}$

Other external assessments confirmed that despite the crisis the banking system was holding up well. For example, following a staff mission by the IMF, the following preliminary finding was issued on 15 February 2011:

"The Cypriot banking system has weathered the economic difficulties well and appears to be in sound overall condition. It has benefited from reliance on deposits rather than less stable sources of financing, conservative lending practices, close attention to capital and liquidity buffers, and vigilant supervision. These factors have helped shield the banking system from the pressures that are prevalent in many other countries."

In light of the government's refusal to adopt sound economic policies, however, risks to the banking system were increasing. Clouds started to emerge after the government lost market access in May 2011 and the July explosion. By year end, a significant vulnerability could be identified, stemming from the intensification of the euro area crisis and associated government decisions. On 29 November 2011, following an Article IV consultation, the IMF concluded:

"The large banking sector, with assets totaling over 8 times GDP by the broadest measure, and with significant exposure to Greece, is a significant vulnerability. Banks face significant capital needs to reflect mark to market valuations on their sovereign bond holdings and to achieve a 9

\footnotetext{
${ }^{16}$ The regulation introduced a minimum Core Tier 1 capital ratio equal to $8 \%$ plus a surcharge equal to the ratio of a bank's assets to the GDP of Cyprus. For the two largest banks, the implied surcharge was somewhat higher than 2\% (See Central Bank of Cyprus, 2012). The two large banks raised over $10 \%$ percent of GDP in capital over a two year period.
} 
percent core tier one capital ratio, as mandated by the European Banking Authority."

\section{Crisis intensification and a loan from Russia}

During the summer of 2011, the euro area crisis intensified. By then, in addition to Greece, Portugal and Ireland that were under troika programs, a number of other euro area economies were under stress. In large part due to the collective mismanagement of the crisis by euro area governments, sovereign bond markets for numerous member states were destabilized (Orphanides, forthcoming). One of the challenges that developed in mid-year was that the Greek program was not progressing according to plan. Some governments (with the German government taking the lead) insisted that losses be imposed on holders of Greek government bonds. In this manner, the Greek case could serve as an example of private sector involvement (PSI) and reduce the burden on governments to make additional loans to Greece. The outcome of the discussions and subsequent government decisions was to create a doom loop between sovereigns and banks with severe adverse effects on banking systems and economies throughout the periphery of the euro area.

On 21 July 2011, the European Union Council decided to demand PSI on Greek debt. The decision, following negotiations with some bank groups, called for a voluntary haircut of Greek debt, up to 21 percent. The two large Cypriot banks had major operations in Greece and as a result held considerable amounts of Greek debt, similar to the practice of all banks operating in Greece. This would have been a painful loss to shareholders. However, the two Cypriot banks had accumulated more than enough capital and could weather this decision with existing buffers.

Unfortunately, both for the euro area in general and for Cyprus in particular, on 26 October 2011 the European Union Council decided to abandon its earlier decision in favor of a plan that was more punishing to the banking system. With regard to PSI, the governments backtracked on their July decision and forced a bigger haircut that eventually translated to about 80 percent of the value of holdings of Greek debt. 
At the same time, they demanded a recapitalization exercise without an agreement on how capital would be provided on a euro area wide basis (a common backstop). The plan called for an elevated Core Tier 1 capital requirement (9\%) and an additional capital buffer to reflect valuation risk of sovereign debt. The banks were asked to mark-to-market their holdings of sovereign bonds for the purposes of this exercise so the dislocation reflected in euro area sovereign bond prices added to the capital needs of the banks. Finally, banks were asked to achieve the elevated capital buffers within just a few months, by the end of June 2012. This was a huge blow to the banking system in Europe causing a massive credit crunch and recession. ECB President Mario Draghi later characterized the episode as a "Lehman" event for Europe.

The decision required unanimous agreement of all governments, including the government of Cyprus. Although the government knew that the adopted decision created a disproportionately large burden for Cyprus, relative to other member states in the euro area, and although it had the power to negotiate a more balanced impact, since the decision could not be taken without unanimous support, it made no effort to do so. The communist government appeared more than happy to support punishing the banks on the island. At that time it was not clear whether the government's decision was deliberate or not.

The 26 October 2011 decision created an additional capital requirement of about $25 \%$ of Cypriot GDP for Cypriot banks. The two banks had extra capital to cover about $15 \%$ of GDP of the added capital requirements that was imposed on them. The largest bank on the island, Bank of Cyprus, could cover virtually all of the required capital with existing buffers and could complete the remainder with the sale of insurance assets. The sale of these assets was put in process and was scheduled to be completed by June 2012, as required by the 26 October decision.

But the second largest bank, Marfin-Laiki, needed to raise additional capital of about $10 \%$ of GDP to reach the $9 \%$ Core Tier 1 threshold. As it was not certain whether the bank would be able to raise the additional capital on its own, this created the possibility that the state might be called to provide temporary support of as much 
as $10 \%$ of GDP to this bank. However, as the sovereign had lost market access, it faced a difficulty: It could not credibly offer the temporary assistance on its own by issuing long-term public debt.

This triggered a negative feedback loop between the financial sector and public debt, as the ECB had warned about in December 2010. With the economy tanking and no access to markets, the sovereign faced default during the second half of 2011, even if Marfin-Laiki had managed to raise the capital it needed to fulfill the requirements of the 26 October 2011 decision on its own. This made it harder for the bank to raise capital. At the same time, concerns about the bank's capital-raising effort created the prospect that the government might need to support the bank, which put additional pressure on the sovereign.

The government could have sought assistance from its European partners and the IMF during the second half of 2011 to resolve the crisis. However, this would have forced the communist party to acknowledge the unsustainability of its fiscal finances and undertake the short-term political cost of implementing unpopular consolidation measures and structural reforms.

The government sought an alternative solution: It negotiated a bilateral loan from the Russian Federation. The loan antagonized the island's European partners. The loan could not solve the government's sustainability problem, just postpone its resolution until a later date. But solving the problem was not the objective. The key was politics. The amount of the loan was calculated so that the government could meet its fiscal needs until the next presidential elections, in February 2013. With the loan, the government could avoid undertaking the meaningful fiscal adjustments necessary to restore market access. The delay in corrective action made the problem worse. Once again, short-term political calculations dominated.

\section{Collateral eligibility as the sword of Damocles}

While the Russian loan permitted the government to delay acknowledging the fiscal unsustainability it had created beyond the February 2013 elections, it was insufficient 
to ensure that Marfin-Laiki would be able to fulfill the capital requirements of the 26 October 2011 decision by June 2012.

A possible solution to the challenge required support from the ECB. If banks could be assured that government debt would remain ECB-eligible collateral, then the government could raise the funds needed through issuance of debt. Banks could finance this debt with liquidity provided by the ECB using the bonds as collateral.

But there was a catch. ECB eligibility required at least one investment-grade rating of sovereign paper. The Cyprus government had suffered such a loss of credibility that it could no longer safeguard its investment-grade rating. Cypriot government debt was barely eligible and one more downgrade would have rendered it ineligible as collateral. This eligibility rule, however, had been waived for program countries. Could Cyprus secure similar support without a program?

This emerged as a possibility in early 2012. With a delay of over a year following receipt of the warning letter from the ECB, the government understood that the ECB was in a position to help the country. An effort to that end started with Finance Minister Kikis Kazamias. In a letter to the ECB on 5 March 2012, the minister first acknowledged that fiscal finances were unsustainable in 2011 and outlined his efforts:

"[S]ince I took the responsibilities of the Minister of Finance in August 2011, I have embarked, in a difficult environment, in a constructive dialogue with all stakeholders to address the structural weaknesses in the area of public finances. At that point public finances were clearly unsustainable and measures were urgently needed." (Kazamias, 2012.)

He then outlined his commitment for further measures to be implemented during 2012. However, before the end of the month Kazamias resigned and Vassos Shiarly assumed the minister's office. Following consultations with the ministry, the Central Bank arranged for direct communication between the ministry and the ECB so the new minister could continue the case for rebuilding the government's credibility. The minister would argue that despite earlier delays, the government would adopt and implement voluntarily fiscal measures similar to what an $\mathrm{MoU}$ would have demanded. 
In this manner the government could avoid a formal support program but argue for support from the ECB.

At a meeting with the Executive Board of the ECB on 17 April 2011 in Frankfurt, Minister Shiarly committed to adopting and implementing specific measures before the end of May. The Ministry of Finance subsequently worked on the plan and submitted it for the consideration of the communist party and the President.

The plan was deemed too politically costly and was resoundingly rejected. A statement by Finance Minister Vassos Shiarly on 1 June indicated his predicament and fading hopes:

"During May 2012 I had repeatedly stated my intent to announce consolidation measures before the end of May with the purpose of correcting the deviation of the budget deficit ... During a radio interview yesterday the incorrect impression was given that I would have announced these measures within the day. What I said was that during the day I would make an announcement relating to these measures but not the measures themselves. Regarding the proposed measures, even with a small but necessary delay lasting a few days, they will be announced soon." (Cyprus News Agency, 2012a, author translation.)

The rift came out in the open later that day, during the President's press conference when a reporter asked about the measures:

"Over the past several days there has been information that plans with fiscal measures have been advanced but these measures have not been announced as expected. Press reports today suggest that the Presidential Palace and AKEL have interfered with these plans. Is this correct?"

The question elicited the following response from the President:

"It is peculiar to ask me whether there has been interference from the Presidential Palace. Who determines the policy of a state where the constitution lays down a Presidential system with executive powers by the 
President? An individual minister or the mandarins in the ministry? ... When the President has seen the Cypriot public in the eye many times and has said that no additional fiscal measures will be taken that harm the workers ... This President means what he says. And for this reason, I did not allow, and will not allow additional burdens imposed on the workers. ... We discuss plans with the ministers and, of course, if these plans are not agreeable to the President ... then this President can stop them. ... And I wish to reassure the public one more time, and the government workers, that neither their bonuses are at risk, nor their pensions are at risk and that no additional measures will be implemented that cut workers' benefits. Period. At least while I am President." (Cyprus News Agency, 2012b, author translation.)

The President's public dismissal of the minister's efforts to implement his commitments to the ECB pushed Cyprus over the cliff. On 25 June 2012, following a downgrade to junk status by Fitch, government bonds no longer met the ECB eligibility criteria and the crisis reached a new peak.

As expected, the ECB did not waive the collateral eligibility rules for Cyprus. Cyprus became the first country in history whose central bank routinely refused to accept its bonds for monetary policy purposes. Concerned about the consequences, the government asked for help from the troika on the same day. Unfortunately, as would become apparent soon after, it had no intention of completing an MoU.

\section{Assault on the banks}

In retrospect it is clear that the communist party never intended to incur the shortterm political costs needed to restore fiscal sustainability. The party's attention had already shifted to the February 2013 presidential election. To that end, the government desperately tried to shift actions that entailed short-run political cost into the future, subsequent to the election.

As a platform for the election, the communist party focused on an assault on 
the banks. ${ }^{17}$ Banks are an easy target for populism. It was desirable for the party to argue that the banks were exclusively to blame for all Cyprus' ills. Control of the Central Bank, the bank supervisor, proved crucial for this purpose. Since the governor's term was ending, the communist party could secure the effective control of the Central Bank on 3 May 2012 with the appointment of a governor who could closely coordinate the Central Bank's actions with the party. ${ }^{18}$ Changes of key senior staff at the Central Bank which followed immediately after the appointment of the new governor, suggested that the Central Bank was losing its independence in favor of closer control by the communist party. ${ }^{19}$ From then on, the government and Central Bank could engage in a coordinated campaign against the banks.

The danger to the country was recognized widely. Even people who had been generally sympathetic to the communist party, like former President George Vassiliou, tried to warn against attacking the banks. Vassiliou is an economist. His presidency saw the advancement of financial services as a growth model for the island. This made him well aware of the consequences of a campaign against the banks. In an interview that was published on 3 June 2012, Vassiliou pleaded with the government to take action on fiscal and structural measures to restore the government's trustworthiness. He insisted: "Our problem is manageable. As long as the proper measures are implemented the soonest." Regarding the banks, he argued that in light of their key role for the island's economy the government should be supportive, adding: "In no other country you will hear the leaders blame the banks ... no one says that the

\footnotetext{
${ }^{17}$ The assault was noted and documented in real time, including by the press. See e.g. Cyprus Mail (2012a,b,c and 2013a,b,c,d) for examples reported in English.

${ }^{18}$ The coordination was noted quickly after the new governor's appointment. For example, a Cyprus Mail editorial on 29 June 2012 explained: "The banks should also take into account another factor - they are facing a hostile government which is doing everything in its power to discredit the banking sector in order to deflect attention away from its responsibilities for the huge problems facing the country. Apart from the government's unrelenting antibank rhetoric, the bank boards will also have to deal with the hostile attitude adopted by the new Central Bank Governor, Panicos Demetriades who heads the government's offensive. ... It is difficult not to question the motives of the Governor, considering the views he expresses in public speeches sound like those of a member of the AKEL Central Committee rather than of an independent state official." (Cyprus Mail, 2012a.)

${ }^{19}$ Financial Mirror (2012) detailed the changes. For example, Spyros Stavrinakis was immediately placed in charge of bank supervision, financial stability, bank licensing and European affairs. He was later appointed Deputy Governor by the communist government but his appointment, which was unconstitutional, was rescinded.
} 
only problem in their economies is the banks." (Drousiotis, 2013, author translation). He failed to convince.

Bank of Cyprus, the island's largest bank, appeared to have been specifically targeted by the Central Bank. The bank's capital plan, which was to be completed with the sale of insurance assets by the end of June 2012, was interrupted as a result of interference with the planned sale. ${ }^{20}$ The bank was then urged to seek assistance from the government. As soon as the bank obliged, it became clear why it had been forced to do so. By forcing the bank to apply for state aid, the Central Bank could launch an investigation that included Bank of Cyprus, examining why the banking system suffered losses and needed state support. Alvarez \& Marsal, was commissioned to undertake this investigation. It soon became apparent that the real focus was to inflict damage to Bank of Cyprus. Selective leaks to the press during the investigation carried out by Alvarez \& Marsal, targeted the bank. ${ }^{21}$

The communist-controlled government and Central Bank also engaged in a coordinated misinformation campaign regarding bank supervision in earlier years. The following example is characteristic of the level of discourse. A story was cultivated that in 2011 the Central Bank had approved an application for the conversion of the Greek subsidiary of Marfin-Laiki bank to a branch. This was characterized as a serious error that cost the government billions of euro. In fact, no such decision was made by the Central Bank as no approval by the Central Bank was needed for the conversion since the banking group was based in Cyprus (Antoniou, 2012). ${ }^{22}$ During the election campaign, the Central Bank refrained from clarifying the facts, which would have exposed the communist party's misinformation. The truth was confirmed

\footnotetext{
${ }^{20}$ As the $\mathrm{CEO}$ of Bank of Cyprus stated at a hearing of the Investigation Committee on the Economy: "Instead of supporting the efforts and providing prompt responses from the European Banking Authority, the governor also torpedoed the efforts to sell the insurance companies through continuous correspondence that created complications in the procedure." (Psyllides, 2013c.)

${ }^{21}$ Curiously, as was later confirmed, Marfin-Laiki, which did need state support, was left out of the investigation. Evidence of a murky relationship between the Central Bank and Alvarez \& Marsal (including secret contracts against the interests of Cyprus) was later uncovered (Psyllides, 2013d).

${ }^{22}$ The conversion was approved by a district court judge in 2010 , following a hearing. The Company Registrar, an agency of the Ministry of Commerce, had the legal authority to question the conversion, if the government wanted to do so, and did not (Eliadi, 2013, Palala, 2013b).
} 
by the Central Bank only when it was forced to do so after the election. ${ }^{23,24}$

In what appeared to be an international campaign towards the defamation of the banking system, the Central Bank started characterizing banking in Cyprus as "casino banking." (Demetriades, 2012.) To justify the description, it was suggested that Cypriot banks offered high rates to collect international deposits and used the deposits to "gamble" on toxic assets. The alleged gambling involved investing too much of bank equity in the government bond market of one euro area member state. It was suggested that this violated supervisory rules on risk management. Purchases of government bonds in the secondary market were described as suspicious and likely associated with illegal kickbacks. The "casino banking" description promoted by the Central Bank stuck and was used effectively against the island later on.

The focus on blaming the banks for their holdings of euro area government bonds was unique in the euro area. The regulatory framework in the European Union, which had been agreed by EU governments prior to the crisis and has been in effect during the crisis, encouraged banks to hold government bonds and tied regulators' hands. ${ }^{25}$ While criticizing the banks as part of the communist party's campaign, the Central Bank failed to note that the European Union Capital Requirements Directive, which codifies the common regulatory rules in effect throughout the EU, exempts government bonds in a country's domestic currency from restrictions and specifies that the holdings of such bonds be assigned a zero-risk weight against capital for

\footnotetext{
${ }^{23}$ The Parliament's Committee on Financial and Budgetary Affairs, requested a copy of the pertinent decisions and approval that the Central Bank had allegedly provided in 2011 to study the matter. Following this request, the Central Bank admitted that no such approval existed because none was requested since it was not required by law (Demetriou, 2013).

${ }^{24}$ European governments had agreed that the member state where a bank group was based would be responsible for support of the group, if needed. As a result, the fact that the Marfin-Laiki group was based in Cyprus was of critical importance. In July 2009, the group considered moving to Greece, a move that would have been welcomed by the Central Bank of Cyprus. The government lobbied to keep the group in Cyprus. Andros Kyprianou, the communist party's General Secretary, explained: "It is true that it is in our interest that the [banking] group whose interests $\mathrm{Mr}$ Vgenopoulos represents should stay, because this is to the benefit of the Cypriot economy" (Cyprus Mail, 2009).

${ }^{25}$ By encouraging the banks to hold sovereign bonds in their own currency, governments reduced the cost of their financing but also created a symbiotic relationship that made banks more vulnerable to sovereign risk. This was a key reason why the PSI-related decisions of the European Council triggered a doom loop between sovereigns and banks in the euro area.
} 
regulatory purposes. ${ }^{26}$ The Central Bank also failed to note that many banks in Europe had much higher multiples of their equity invested in the government bonds of just one country. In addition, the campaign against the banks obscured the pivotal role of the government in the decision on the Greek PSI on 26 October 2011 which resulted in an unequal and highly unfavorable treatment for Cypriot banks relative to Greek banks with similar operations. ${ }^{27}$

The emphasis on blaming the banks during the election campaign was revealing regarding the government's intentions on the Greek PSI. The issue on which the communist party focused its attacks on the banks had been created by the government's decision to impose disproportionate losses on Cypriot banks on 26 October 2011.

Was the government's decision a mistake reflecting incompetence or a deliberate action meant to create an issue that the communist party could later exploit politically? The question is difficult to address authoritatively without access to the deliberations of the Central Committee of the communist party. On the last day of the administration, Finance Minister Shiarly argued that the decision was a "mistake" reflecting "excessive zeal to show solidarity." Specifically, he identified two "big mistakes" committed:

"The excessive zeal to show solidarity beyond our capabilities to another eurozone country. We should have put some conditions down, and examined how much our pockets could take. The other is that for consecutive years now we have created excessive public deficits, that have accumulated and reached the point where we can no longer take them." (Evripidou, 2013).

\footnotetext{
${ }^{26}$ This remains the case today, highlighting the inconsistency of government decisions. Section 2 of the regulation, as agreed by the Council in 2013, specifies: "Exposures to Member States' central governments, and central banks denominated and funded in the domestic currency of that central government and central bank shall be assigned a risk weight of 0\%." (European Union, 2013.) Weidmann (2013) noted this may be a case of the "principle of unripe time."

${ }^{27}$ For example, according to data associated with the 2011 EBA stress test, Piraeus Bank had Greek sovereign exposures amounting to $271 \%$ of Core Tier 1 capital. Other banks had even greater exposure. By comparison, the highest exposure in Cyprus was 169\% of Core Tier 1 capital, for Marfin-Laiki bank. The majority of operations of both of these banks were in Greece. Following the 26 October 2011 decision, Piraeus Bank was fully supported, despite its negative capital position, while Marfin-Laiki bank, which continued to have positive capital after the PSI, was later shut down.
} 
While not implausible on its own, the "mistake" explanation is harder to reconcile with the communist party's subsequent zeal to exploit the "mistake" for political gain rather than correct it. The subsequent behavior of the communist-controlled government and Central Bank strongly suggested that inflicting damage to the banking system was deliberate. Had the government insisted on a more balanced approach to the Greek PSI decision, the banks would not have had problems that could be exploited politically. ${ }^{28}$ The government's stance on 26 October 2011 made the banks the very target the communist party needed to deflect attention from the government's failure to manage the country, especially following the explosion on 11 July 2011.

Blaming the banks for the losses the government had imposed on them with the Greek PSI decision became a focal element of communist party rhetoric. A characteristic example was the following statement by Government Spokesman Stefanos Stefanou on 31 May 2012:

"The basic problem facing the Cypriot economy is the large exposure of Cypriot banks to Greek government bonds, whether some want to hear it here in Cyprus or not." (Michaelides, 2012, author translation.)

During the February 2013 presidential election campaign, the communist party tried to convince the public that its government had nothing to do with the losses imposed on the banks. Numerous incredible and shifting claims were floated. It was suggested that the Greek PSI had been decided by the ECB. It was argued that the Cypriot government had no information of the holdings of Greek bonds by Cypriot banks before key decisions were made. It was argued that the government was not aware of the disproportionate losses it imposed to the country by supporting the 26 October 2011 PSI decision. In fact, information from the Minutes of a Council of Ministers meeting in Nicosia on 25 October 2011 confirmed that both the Minister of Finance and the President were aware of the disproportionate cost of the Greek PSI

\footnotetext{
${ }^{28}$ Right after the collapse in March 2013, the governor admitted that "the two large banks would have been in a very good position without the Greek PSI." (Palala 2013a, author translation.)
} 
plan to Cyprus that was to be decided in Brussels the following day. ${ }^{29}$

The main challenge for the communist party during the election campaign was to explain why the country had lost market access and the government had to engage in negotiations for an MoU with the troika. It was known that the government needed about 8 billion euro for its fiscal needs, whereas until April 2012 about 2 billion euro was sufficient to meet the capital needs of the banks that arose from the 26 October 2011 decision. The communist party's claim was that the only reason its government had to engage in negotiations with the troika was the banks. To make this claim credible, help from the Central Bank was required. The Central Bank could take steps during the election campaign and make the capital needs of the banks appear larger than the 8 billion fiscal gap. Indeed, various statements and leaks to the press starting right after the government applied for a troika program suggested that the capital needs of the banking system could well be around 10 billion euro, comfortably above the 8 billion euro fiscal gap. The communist party relied heavily on this comparison during the election campaign to support the claim that the only reason the government had to seek EU/IMF assistance was problems with the banks.

The Central Bank had sufficient discretion to worsen the position of the banks and raise estimates of the capital needs of the banking system before the elections. Stricter guidelines and changes of definitions regarding non-performing loans forced banks to abruptly raise provisions, worsening their capital ratios. More importantly, a contract was awarded to PIMCO in the context of the troika negotiations to provide independent estimates of the capital needs of the banking sector. However, the independence of the exercise was limited as the methodology and key parameters employed by PIMCO were governed by a steering committee which was headed by the Central Bank. ${ }^{30}$

When preliminary results were rumored to match the outsized bank capital needs that suited the communist party's election rhetoric, questions arose about PIMCO's

\footnotetext{
${ }^{29}$ However, this information was withheld from the public and was only disclosed after the election.

${ }^{30}$ The steering committee included members from the Ministry of Finance and the troika and it took decisions by consensus. As a result, by chairing the committee, the Central Bank effectively led the process.
} 
selection and the Central Bank's intentions. Through its control of the methodology and key parameters about a hypothetical adverse scenario which formed the basis of the exercise, the Central Bank had the flexibility to make the exercise stricter than similar exercises that had been done elsewhere which could lead to overestimation of the banks' capital needs. ${ }^{31}$ Additional concerns emerged when it was revealed that, contrary to normal practice, there were no consultations between PIMCO and the banks to ensure that the assumptions employed were appropriate. The Chairman of Bank of Cyprus, Andreas Artemis, later noted before the Investigation Committee on the Economy:

"PIMCO refused persistently to discuss with the banks either the assumptions or its findings, despite repeated written requests from us to the governor, and our warnings that the rumored overestimation would be catastrophic both for the banks and for the economy." (Artemis, 2013, author translation.)

One report offered the summary: "PIMCO mess reeks of political expediency" (Psyllides, 2013a).

Political parties and other stakeholders (except for the communist party and the institutions then under its control) expressed concerns about the implications of the PIMCO analysis before it was finalized, while it could still be corrected. On 8 January 2013, the Economics Committee of the Parliament held a hearing on the matter. But without the cooperation of the Central Bank, the interests of the country could not be defended. And since the exaggeration of the capital needs in the banking system had become a crucial element of the communist party's campaign, cooperation from

\footnotetext{
${ }^{31}$ PIMCO was not the most obvious choice for this exercise when it was selected by the Central Bank of Cyprus as other companies had more direct experience in the region. For example, BlackRock had conducted a similar exercise in Greece and could have applied the same methodology it had used for that exercise, especially since Cypriot banks had substantial operations in Greece. In light of the methodology that had already been applied in Greece, had BlackRock been selected for the exercise, the estimated capital needs would have been lower. It was subsequently disclosed that BlackRock had shown interest in undertaking the exercise but, according to the Governor of the Central Bank, its bid was rejected because of a "conflict." (Tsouroullis, 2013.)
} 
any institution under the party's control was impossible. ${ }^{32,33}$

Evidence presented later to the Investigation Committee on the Economy confirmed that the PIMCO analysis severely overestimated banks' capital needs (Nicolaou, 2013). The exaggeration in the PIMCO estimates may have exceeded 20 percent of Cypriot GDP. ${ }^{34,35}$

\section{The haircut}

While it met the needs of the communist party for the presidential campaign, the coordinated campaign against the banks also succeeded in creating the image that the banking system was so severely undercapitalized that if the government were to provide the capital, as was done in previous cases, then, according to standard IMF analysis, government debt could be deemed unsustainable. The debt-to-GDP ratio was projected to rise to as much as 140 percent if the government injected capital to the banks based on the PIMCO figures. Claims of unsustainability would not have been supported without the exaggeration of the capital needs of the banks. The PIMCO estimates also suggested that the Central Bank provided Emergency Liquid-

\footnotetext{
${ }^{32}$ An editorial article authored by the General Secretary of the communist party, Andros Kyprianou, was indicative of the communist party's position on the matter (Kyprianou, 2013).

${ }^{33}$ As a result of calls to explain its actions, the Central Bank attempted to shift the blame to PIMCO for the adverse methodology and assumptions. Mogelof and Stracke (2013) responded that "assumptions that have been described as PIMCO inputs in your letter were, in fact, direct inputs from the Steering Committee," thus confirming the role of the Central Bank in arriving at the inflated estimates (Drousiotis and Georgiades, 2013, and Psyllides, 2013b.)

${ }^{34} \mathrm{~A}$ report to the Investigation Committee, based on confidential information including a subsequent report by BlackRock, concluded that the capital needs of the banking system were between 0.7 and 2.4 billion euro instead of the 5.7 billion estimate provided by PIMCO (Zenios, 2013). The adverse treatment of Cyprus was also acknowledged by the IMF: "Furthermore, unlike previous exercises in peer countries, PIMCO has used a more conservative methodology in arriving to the final numbers" (International Monetary Fund, 2013).

${ }^{35}$ The inflated PIMCO estimates were also used to transfer assets of Cypriot banks to Piraeus Bank in Greece, thus reversing the negative equity position of Piraeus Bank from -2.7 billion euro on 31 December 2012 to +0.9 billion euro on 31 March 2013. The transfer amounted to about 20 percent of Cypriot GDP. It was executed by the Central Bank of Cyprus through a forced sale of assets of Cypriot banks to Piraeus Bank, over the objections of the Cypriot banks. By using the PIMCO valuation to arrive at the forced sale price while an alternative valuation could be used by Piraeus Bank, a windfall profit of 3.4 billion euro was recorded from the deal (Piraeus Bank, 2013).
} 
ity Assistance to Marfin-Laiki while it was insolvent, in violation of legal statutes. ${ }^{36,37}$

In this environment, it was considered that the recapitalization of banks in Cyprus should include "internal measures" i.e. losses imposed on deposits, bonds and securities. The Central Bank had indicated that it favored this approach (Demetriades, 2012). While the implementation of such plans would effectively destroy the banking system in Cyprus, with a huge cost to the country, this could be justified in light of the position of the Cypriot authorities that the root of the problems in Cyprus was "casino banking." In this way, the coordinated campaign against the banks in the context of the February 2013 election, led to the haircut of deposits in Cyprus.

Financial analysis and reports in international press started pointing to the inevitable conclusions before the election. On 10 January 2013, the New York Times reported that: "Officials in Brussels and Berlin are said to be considering a controversial plan that could require depositors in Cypriot banks to accept losses on their savings." (Thomas, 2013.) In its Euro Economics Weekly on 11 January, Citi Research noted: "We think a bail-in of uninsured depositors is probably the only option that would restore the country's financial sustainability." (Citi Research, 2013, p. 1.) In a special report on 17 January, Medley Global Advisors noted: "The long delay in negotiating a Troika program, the intransigence of communist President Demetris Christofias and the outsized presence of Russian savers in Cypriot banks have all given rise to speculation that the government will either be allowed to default or face haircuts on sovereign or bank bonds or even deposits." A week later, on 24 January, the Wall Street Journal reported: "[R] escue loans could be reduced and the Cypriot debt left more sustainable if some depositors were bailed in ... in other words, some depositors wouldn't get all their money back." (Fidler, Steinhauser and Stevis, 2013.) The opening sentence in a Financial Times article on 10 February stated: "A radical new option for the financial rescue of Cyprus would force losses on uninsured

\footnotetext{
${ }^{36}$ Xiouros (2013) presents pertinent analysis.

${ }^{37}$ In an interview on 26 March 2013, the governor explained the rationale for the decision as follows: "This was not something pleasant, but we had to sustain the bank. It was required to sustain the bank in order for the elections to take place, a new government to come to power, take its decisions, reach an agreement with our European partners, to avoid bankruptcy of the bank and the state." (Palala, 2013a, author translation.)
} 
depositors in Cypriot banks, as well as investors in the country's sovereign bonds, according to a confidential memorandum prepared ahead of Monday's meeting of eurozone ministers." (Spiegel and Peel, 2013.) And on 21 February, the Financial Times published an editorial that concluded: "[W]riting down senior creditors - even uninsured deposits - is the best way to go." (Financial Times, 2013.)

In Cyprus, the first official reference to the haircut was made by Andros Kyprianou, the General Secretary of the communist party, on February 8, 2013. (InBusiness News, 2013). In a television interview, he acknowledged that a contribution from depositors to meet the banks' capital needs had been discussed and said that the proposal suggested that "depositors contribute towards covering bank capital needs ... significant amounts." (Author translation.) Unsurprisingly, in light of such remarks, substantial outflows of deposits from Cyprus were recorded. By the time of the presidential elections later in the month, it had become clear that the communist-controlled government and Central Bank had ensured that a program for Cyprus would have included deposit haircuts and the subsequent destruction of the banking system.

The election was over on 24 February 2013. The communist party did well but it lost. In the first round, the party's candidate managed to secure second place, as it had managed in 2008. Also as in 2008, the runoff pitted the communist-party candidate against a right-wing candidate. In the runoff, the communist-party candidate secured only 43 percent of the vote and lost the presidency. A new government was formed on 1 March 2013. It was too late.

The economic consequences of five years under communist control were severe. By 2012, real GDP per person had fallen cumulatively by more than 10 percent relative to 2007 (Figure 10). Worse, as a consequence of the damage to the economic model of the island, the decline was projected to continue. 


\section{Concluding Remarks}

Was there a different path? The government's refusal to engage in meaningful dialogue with its European partners suggests that an alternative path was out of the question while the communist party remained in power. Consider that Cyprus held the presidency of the European Union during the second half of 2012, the crucial period when it desperately needed assistance. Any other government would have leveraged the status presented by the occasion and negotiated a program which should have achieved at least equal terms to earlier programs. Instead, the government antagonized and alienated its peers. President Christofias' last appearance in front of the European Parliament at the conclusion of the Cyprus Presidency was characteristic. While the plan that would destroy the economic model of the island was being finalized, President Christofias used the occasion on 15 January 2013, to complain:

"[A]t last, some should free themselves from the syndrome against communism because I have faced this bias ever since my first visit to the European Parliament. I expressed by respect, I said that I am proud because I am a communist and continue to be proud and will be until the end of my life." (European Parliament, 2013, author translation.)

The foremost guide for the government's actions was avoidance of short-term political cost. This led to repeated miscalculations. In retrospect, the July 2011 disaster in Mari could have served as a guide to the government's subsequent decisions regarding the economy: Deliberate inaction transformed a small and easily manageable initial risk into a catastrophe. In Mari, the problem was simple to identify. Storing explosives in metal containers in extremely high temperatures for a long time is dangerous. Despite repeated warnings regarding the dangers, the government opted to do nothing. The government's inaction made the problem increasingly bigger and eventually led to the massive explosion on 11 July 2011.

The government's actions on the economy followed the same script. Inaction was chosen over correcting a fiscal imbalance that was initially small and easily manage- 
able. The communist party opted to avoid short-term political cost. The party that supposedly protected the "working people" could not come to terms with acknowledging that its policies had raised government expenditures to unsustainable levels. Unlike the disaster in Mari, however, in the case of the economy deliberate actions transformed a manageable problem into a catastrophe. To deflect attention from its mismanagement of the economy, the communist party assaulted the banks.

The coordinated assault of the banking system by the communist-controlled government and Central Bank was successful. At a very high cost to the country.

The direct loss imposed to Cypriot banks as a result of the assault was about 8 billion euro - 4.6 billion to the Greek state from the PSI and 3.4 billion to Piraeus Bank. The total represents about one half of 2013 GDP for Cyprus. The indirect loss is even higher. As former President George Vassiliou had warned in an interview in July 2012: "The war against the banking sector is a war against Cyprus ... if you destroy the banking sector you destroy everything." (Psyllides, 2012.) The communist party chose to disregard all warnings about the severe consequences of its policies for the country. The result was the destruction of the economic model of the island and a severe deterioration of economic prospects for the "working people" the party supposedly protected.

In the five-year period, 1 March 2008 to 28 February 2013, Cyprus became the one and only European Union member state to be governed by a communist party. In light of the devastation this has caused, one can only hope that this was the last communist government in Europe. By ruling Cyprus for five years, the communist party made the island a case study on how destructive economic populism can be. A lesson I recall learning from Rudi Dornbusch while studying at MIT about other crises that could have been avoided. As Rudi used to say: "Populism always ends in tears." 


\section{References}

Antoniou, Loizos (2012). Presidential lie worth 4.5 billion euro. Alithia, 14 October. (In Greek.)

Artemis, Andreas (2013). Statement to the Investigation Committee on the Economy. 7 July. (In Greek.)

Basel Committee on Banking Supervision (2012). Core principles for effective banking supervision. Bank for International Settlements, September.

Central Bank of Cyprus (2010). The use of the loan-to-value ratio as a macroprudential policy tool: the case of Cyprus 2007-2008. Box A.1, Bulletin, p. 42-46, December.

Central Bank of Cyprus (2012). Annual Report 2011, Nicosia.

Citi Research (2013). Euro Economics Weekly, 11 January.

Cyprus Mail (2009). Is there something behind the 'Vgenopoulos conspiracy? 16 July.

Cyprus Mail (2012a). Island's banks need to rebuild their image, 29 June.

Cyprus Mail (2012b). Time for widespread bank bashing to stop, 15 July.

Cyprus Mail (2012c). Probability of a run on the banks increases daily, 15 November.

Cyprus Mail (2013a). Central Bank Governor more punisher than protector, 31 January.

Cyprus Mail (2013b). Central Bank Governor washes his hands of PIMCO estimates, 21 February.

Cyprus Mail (2013c). EU partners must not make us pay the price of AKEL years, 3 March.

Cyprus Mail (2013d). Only interests served by bank memo leak are CB chief's own, 8 March.

Cyprus News Agency (2012a). Statement by the Finance Minister, Mr. Vassos Shiarly, 1 June. (In Greek.)

Cyprus News Agency (2012b). Press Conference of the President of the Republic, 1 June. (In Greek.)

Demetriades, Panicos (2011). Misguided, unfortunate and provocative. Stockwatch, 22 July. (In Greek.) 
Demetriades, Panicos (2012). Cyprus financial crisis: the framework for an economic recovery within the eurozone. 11 December.

Demetriou, Yiangos (2013). Letter to Nicolas Papadopoulos, Chairman of the Committee on Financial and Budgetary Affairs, 12 September. (In Greek.)

Drousiotis, Makarios (2012). Vassiliou: I hope Demetris is right. Politis, 3 June. (In Greek.)

Drousiotis, Makarios and Demetris Georgiades (2013). You determined the parameters. Politis, 20 February. (In Greek.)

Eliadi, Katerina (2013). Without permission from Central Bank the merger between Laiki - Marfin Egnatia. Alithia, 17 September. (In Greek.)

European Commission (2008). Economic Forecast: Spring 2008, April.

European Commission (2009). 2009 Ageing Report: Economic and Budgetary Projections for the EU-27 Member States (2008-2060).

European Commission (2012a). 2012 Ageing Report: Economic and Budgetary Projections for the EU-27 Member States (2010-2060). May

European Commission (2012b). Fiscal Sustainability Report 2012. December.

European Parliament (2013). Review of the Cyprus Presidency (debate), 15 January. (Parts in English and Greek.)

European Union (2013). Regulation (EU) No 575/2013 of the European Parliament and of the Council of 26 June 2013 on prudential requirements for credit institutions and investment firms and amending Regulation (EU) No 648/2012. Official Journal of the European Union, 27 June.

Evripidou, Stefanos (2013). Shiarly: we made two big mistakes. Cyprus Mail, 1 March.

Fidler, Stephen, Gebriele Steinhauser and Matina Stevis (2013). Rifts over Cyprus bailout feed broader fears. Wall Street Journal, 24 January.

Financial Mirror (2012). You go there, you come here at the Central Bank. 27 June. (In Greek.)

Financial Times (2013). Cyprus is Europe's golden opportunity: Write down creditors instead of burdening the sovereign. 21 February.

InBusiness News (2013). Kyprianou: Pressure for a contribution by depositors, 8 February. (In Greek.) 
International Monetary Fund (2013). Cyprus: Request for Arrangement Under the Extended Fund Facility, IMF Country Report No. 13/125, May.

Kazamias, Kikis (2012). Challenges in the Cyprus Economy. Letter to ECB President Draghi, 5 March.

Kyprianou, Andros (2013). Regarding PIMCO and reality. Simerini, 26 February (In Greek).

Medley Global Advisors (2013). EU Walking on Eggshells. Special Report. 17 January.

Michaelides, Aristos (2012). Who is threatened with default. Phileleftheros, 6 June. (In Greek.)

Ministry of Finance (2010). 2011 Budget: Tidy up the economy, support growth and social policy. Presentation, 15 September. (In Greek.)

Ministry of Finance (2011). Report on the state of the Cypriot Economy. Memorandum to General Secretary, 29 March. (In Greek.)

Mogelof, Eric and Christian Stracke (2013). Letter sent by PIMCO to the Central Bank of Cyprus, 4 February.

Nicolaou, Eliana (2013). Investigation Committee for the economy: Conclusions. 28 September. (In Greek.)

Orphanides, Athanasios (forthcoming). The sovereign debt crisis in the euro area. Ekonomia.

Orphanides, Athanasios and George Syrichas (2012). The Cyprus economy: Historical review, prospects and challenges. Central Bank of Cyprus, Nicosia.

Palala, Nansia (2013a). Towards removing the governor. Simerini, 27 March. (In Greek.)

Palala, Nansia (2013b). The court approved the merger. Simerini, 17 September. (In Greek.)

Pantelides, Poly (2013). Stavrakis: I was just doing my job. Cyprus Mail, 6 June.

Piraeus Bank (2013). Financial statements information for the period from 1st January 2013 to 31st March 2013, 20 May.

Polyviou, Polys (2011). Report of investigation committee regarding the explosion of 11 July 2011 in the naval base Evangelos Florakis at Mari, 30 September. (In Greek.) 
Psyllides, George (2012). If the banks go it all goes. Cyprus Mail, 15 July.

Psyllides, George (2013a). PIMCO mess reeks of political expediency. Cyprus Mail, 7 February.

Psyllides, George (2013b). War of words over PIMCO report. Cyprus Mail, 21 February.

Psyllides, George (2013c). Former BoC boss slams Christofias government. Cyprus Mail, 3 Aptil.

Psyllides, George (2013d). Damning report against CBC governor, Cyprus Mail, 1 December.

Spiegel, Peter and Quentin Peel (2013). Radical rescue proposed for Cyprus. Financial Times, 10 February.

Thomas, Landon (2013). In Cyprus, questions of whether depositors should shoulder the bill, New York Times, 10 January.

Tsouroullis, Chrysanthos (2013). Interview with Panicos Demetriades. Sigma TV, Sixty Minutes, season 7, episode 7, 18 December.

Weidmann, Jens (2013). Stop encouraging banks to buy government debt. Financial Times. 30 September.

Xiouros, Costas (2013). Handling of the emergency liquidity assistance of Laiki bank in the bailout package of Cyprus, working paper, April.

Zenios, Stavros (2013). The collapse of the Cyprus economy: From misjudgment to mismanagement. Report to the Special Investigation Committee for the Cyprus economy. Nicosia, September. 
Figure 1

\section{Introduction of the Euro in Cyprus}

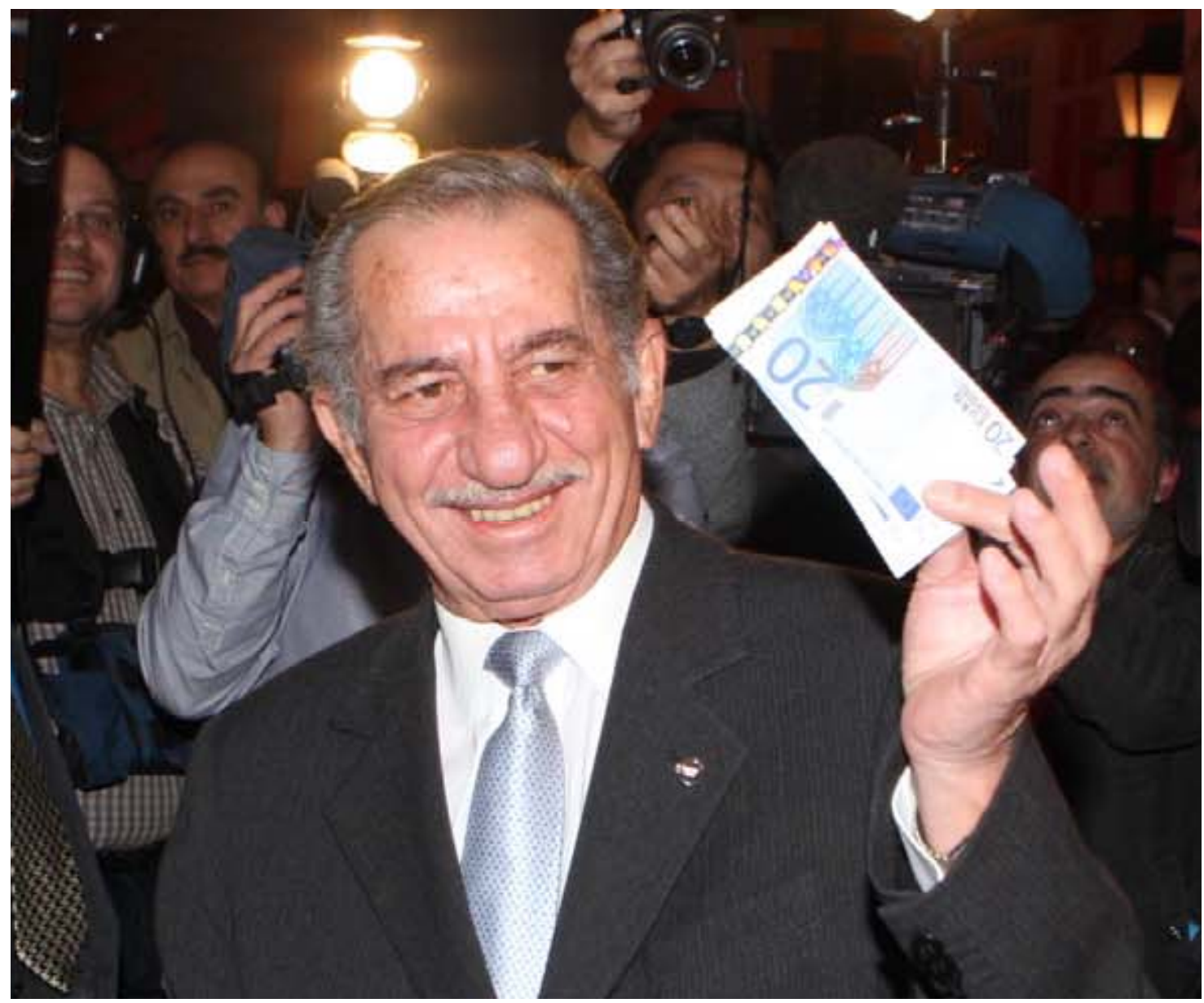

Notes: President Tassos Papadopoulos holding new euro bills at a celebration of the introduction of the euro in Cyprus that took place at the Ministry of Finance in Nicosia just after midnight on 1 January 2008. 
Figure 2

Five-year CDS Spreads on Sovereign Debt

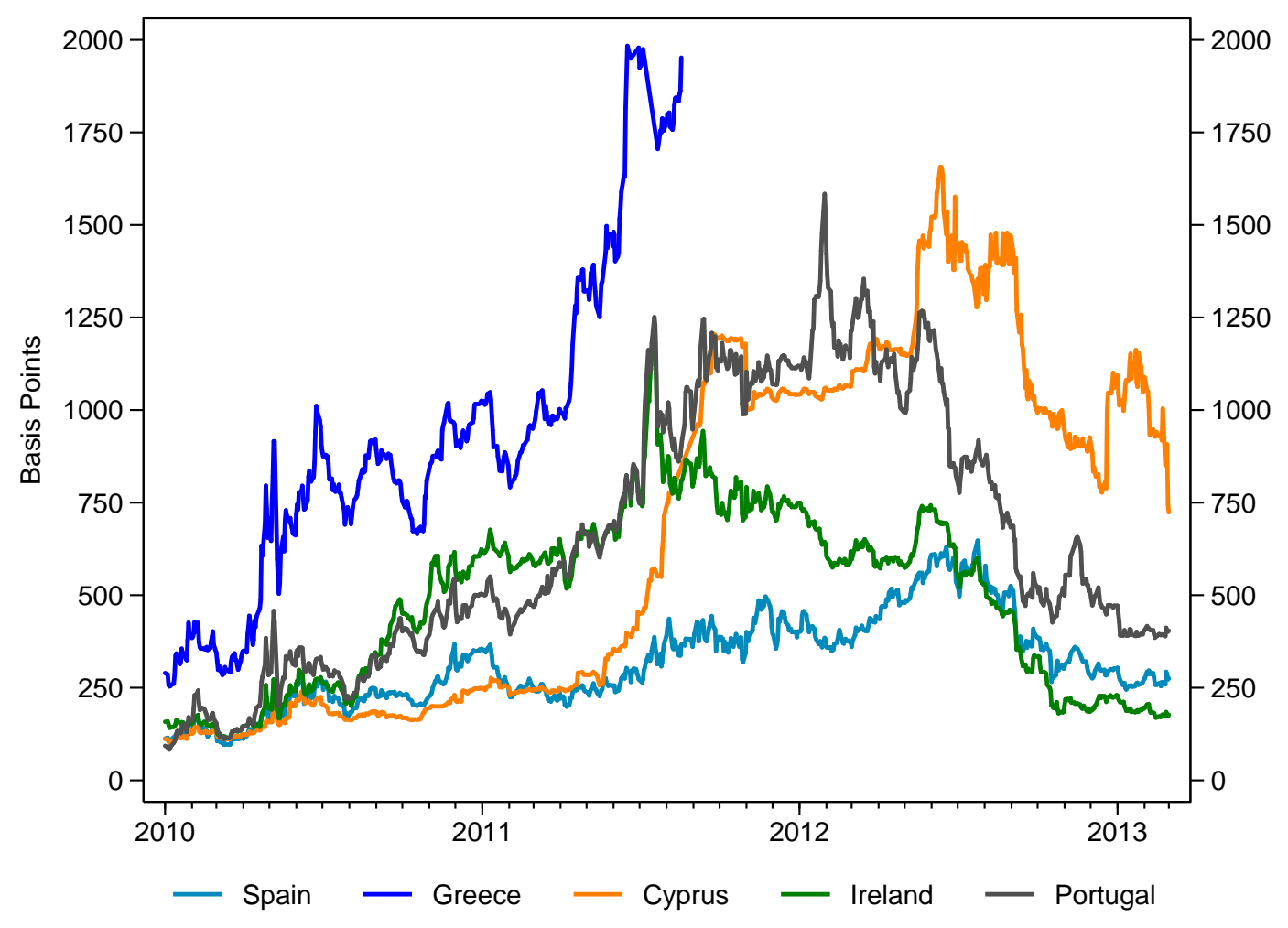

Notes: Daily data, last observation shown is 28 February 2013. 


\section{Figure 3}

\section{The Unique and Damaging Delay}

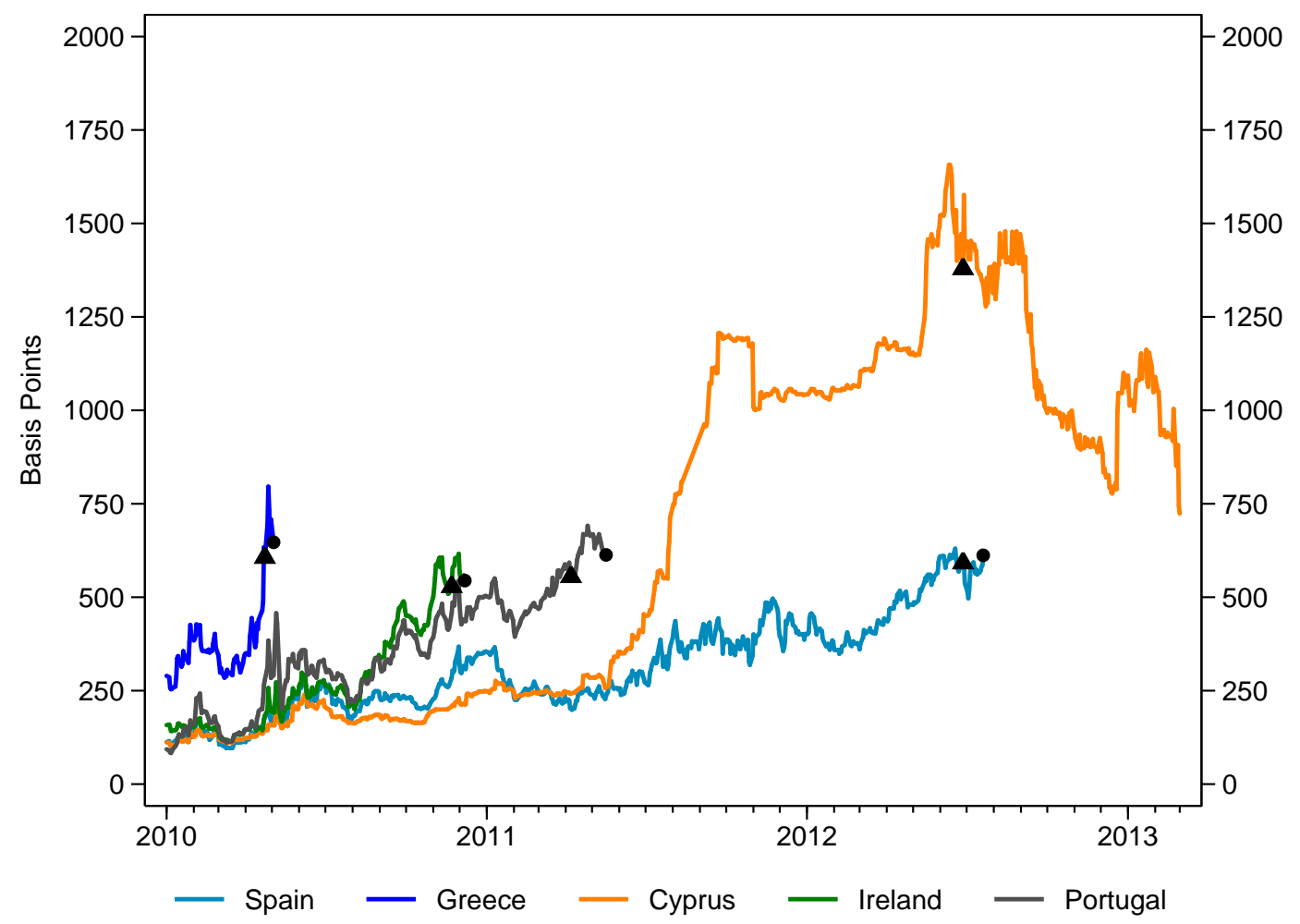

Notes: Daily data on five-year CDS spreads. For each country, a triangle marks the date on which assistance from EU/IMF was requested and a circle marks the date on which a program was agreed and its implementation started, which is also the last observation plotted for the country. No circle is shown for Cyprus as the government refused to conclude a program agreement by 28 February 2013 (the last day of the communist party administratiion). 
Figure 3

Unemployment Rate

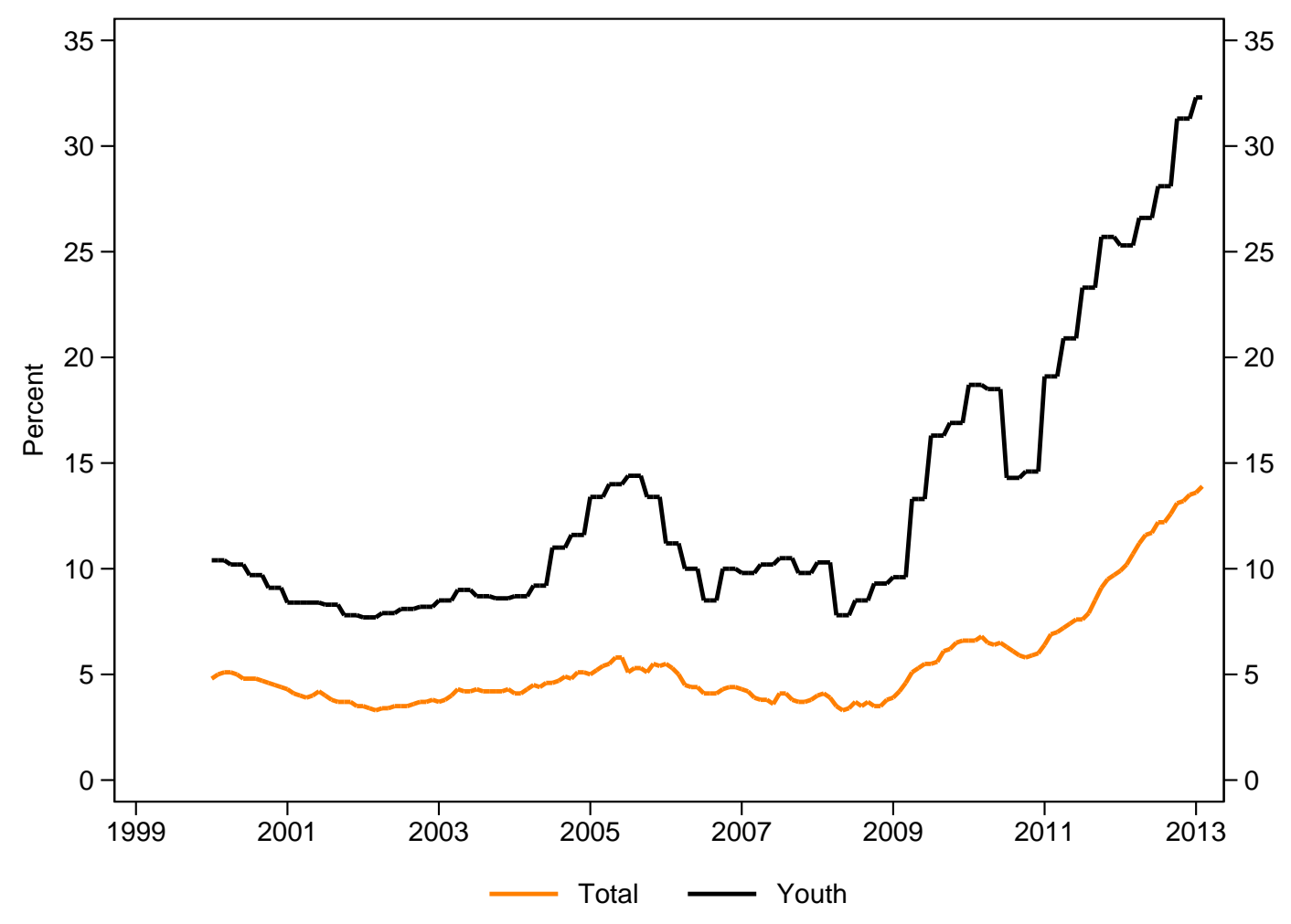


Figure 4

Real GDP

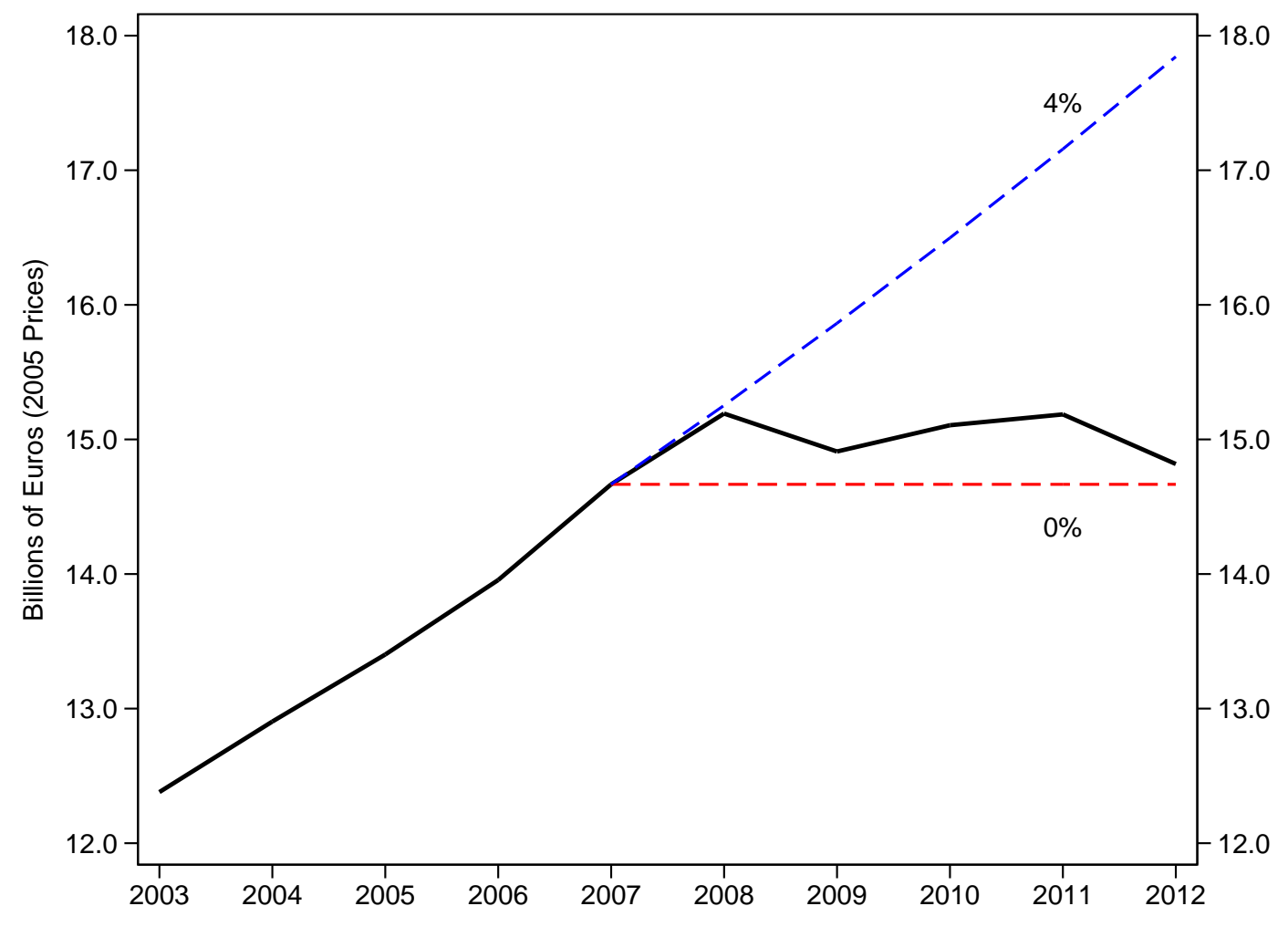


Figure 5

Real Government Expenditures

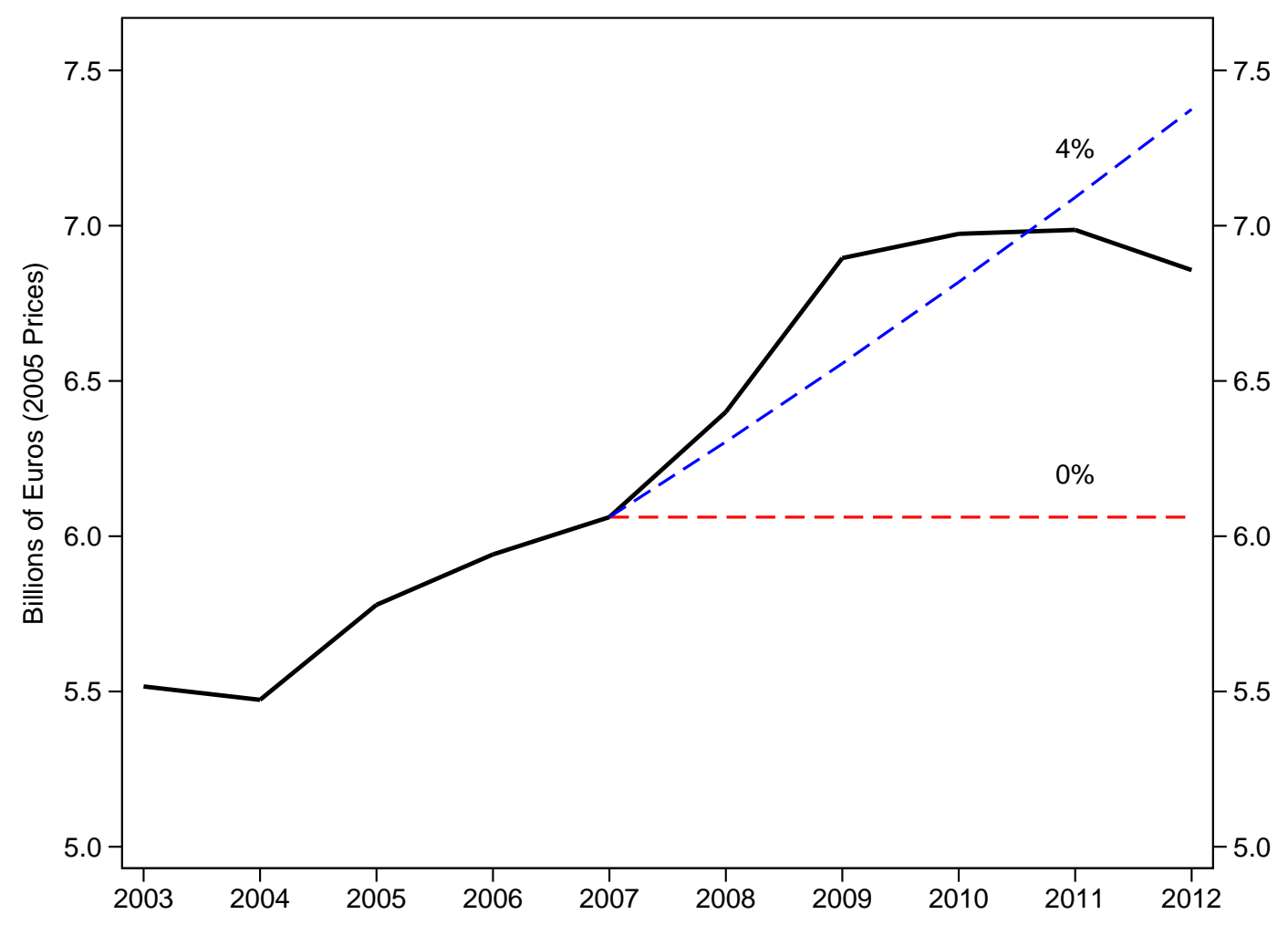




\section{Figure 6}

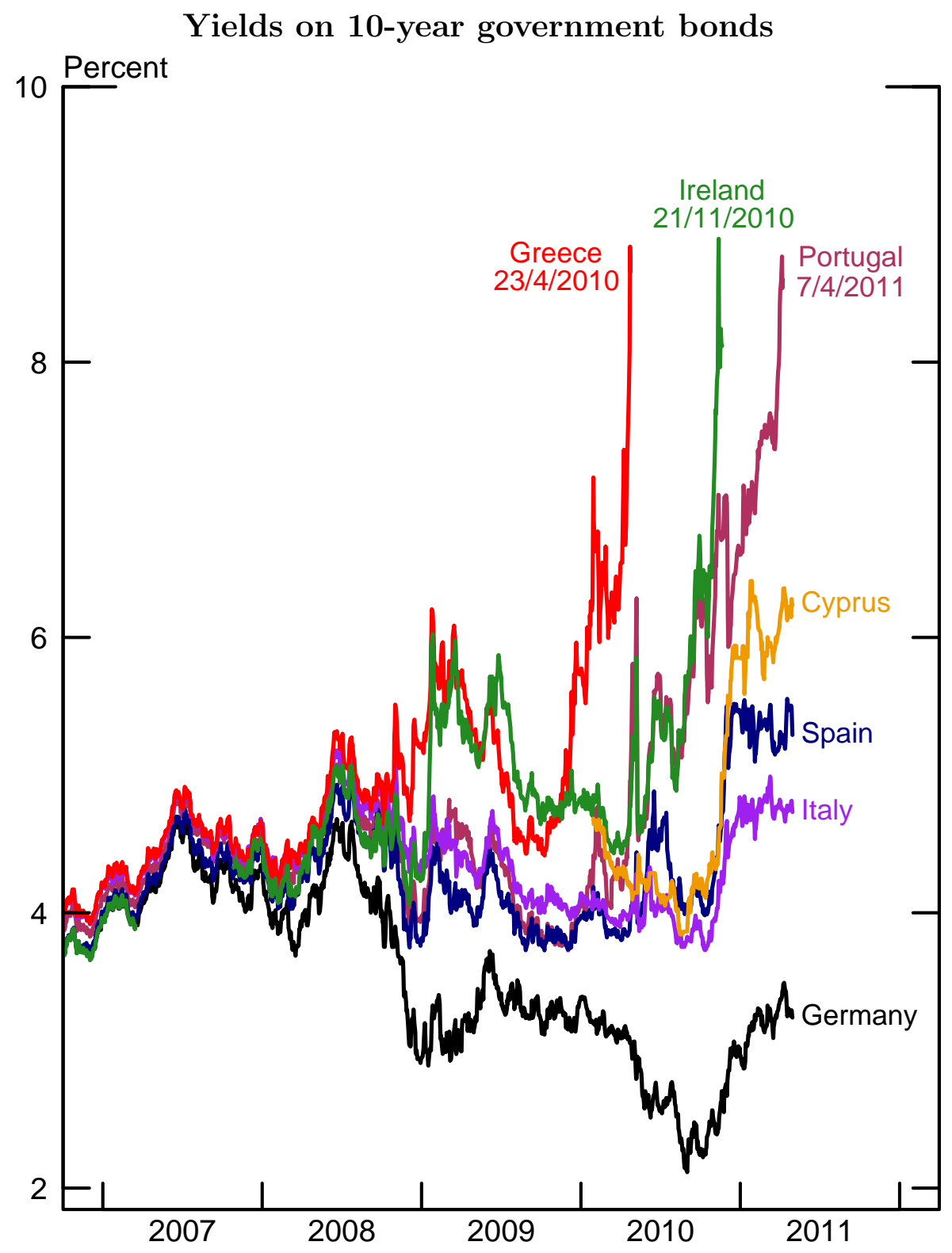

Notes: Last observation shown is 9 May 2011. 


\section{Figure 7}

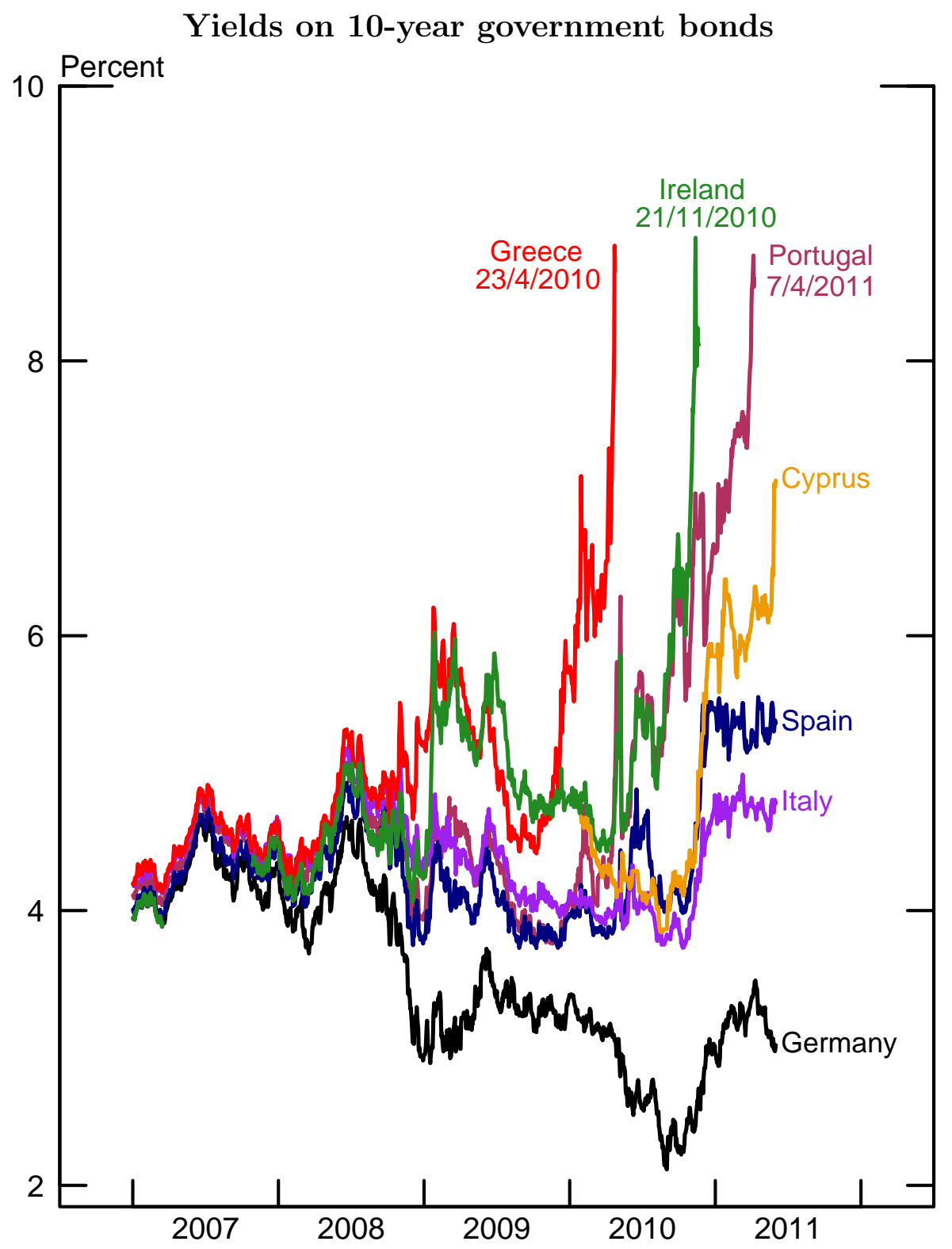

Notes: Last observation shown is 31 May 2011. 


\section{Figure 8}

Yields on 10-year government bonds

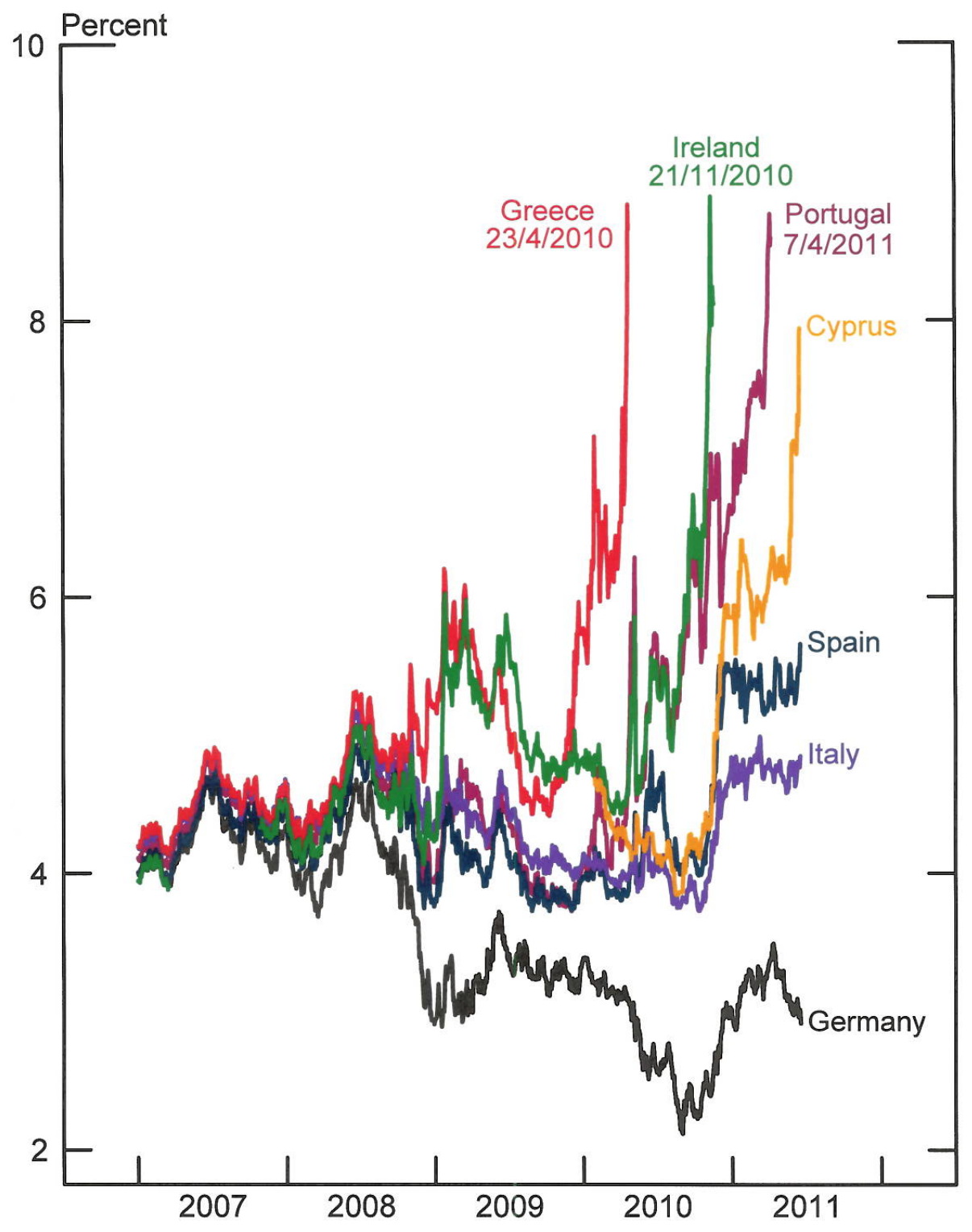

Notes: Last observation shown is 16 June 2011. 
Figure 9

The Iran-Syria arms connection

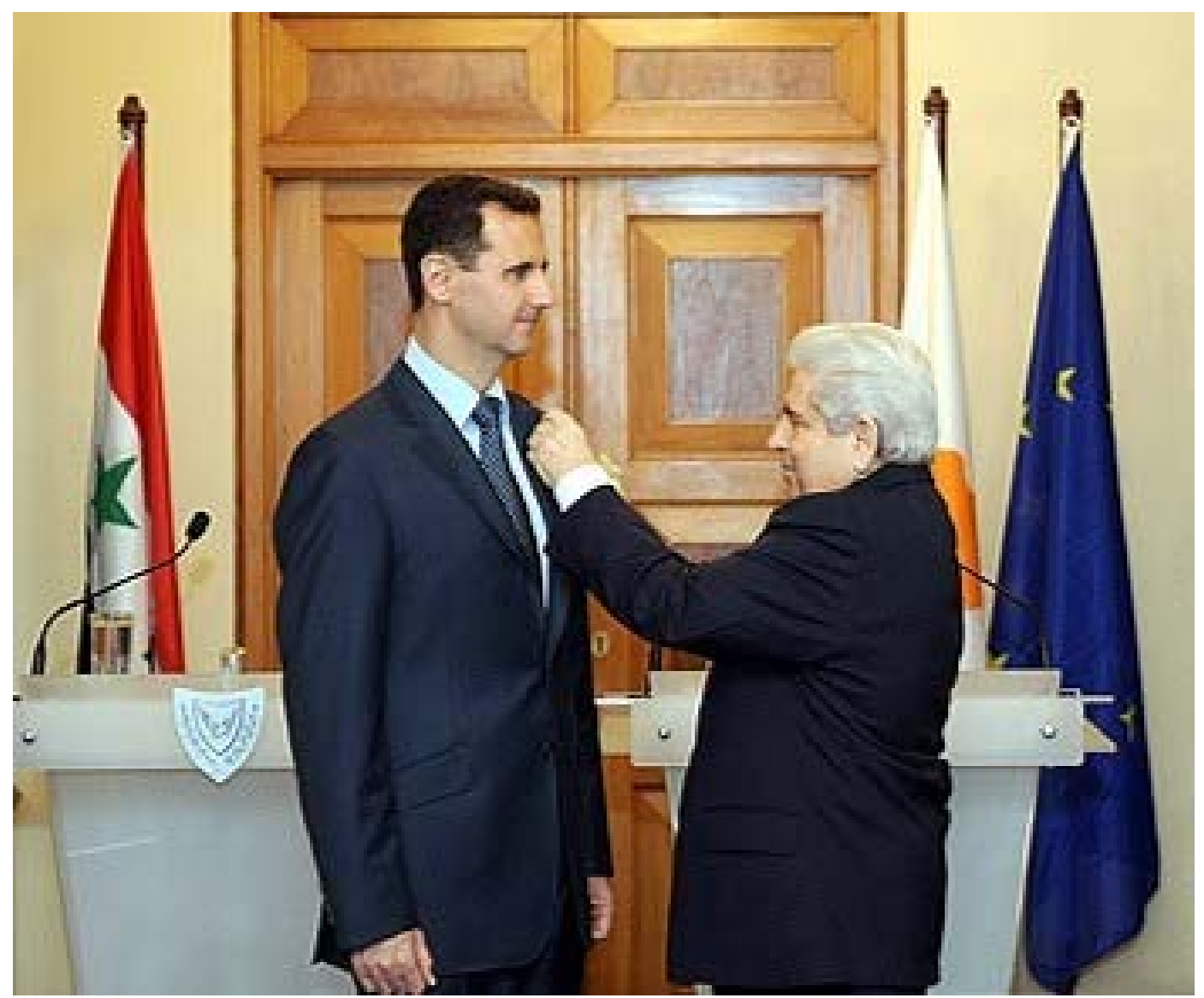

Notes: President Christofias presenting President Assad the Grand Cross of the Order of Merit of the Republic of Cyprus on 5 November 2010 at the Presidential Palace in Nicosia. 
Figure 10

Real GDP per person

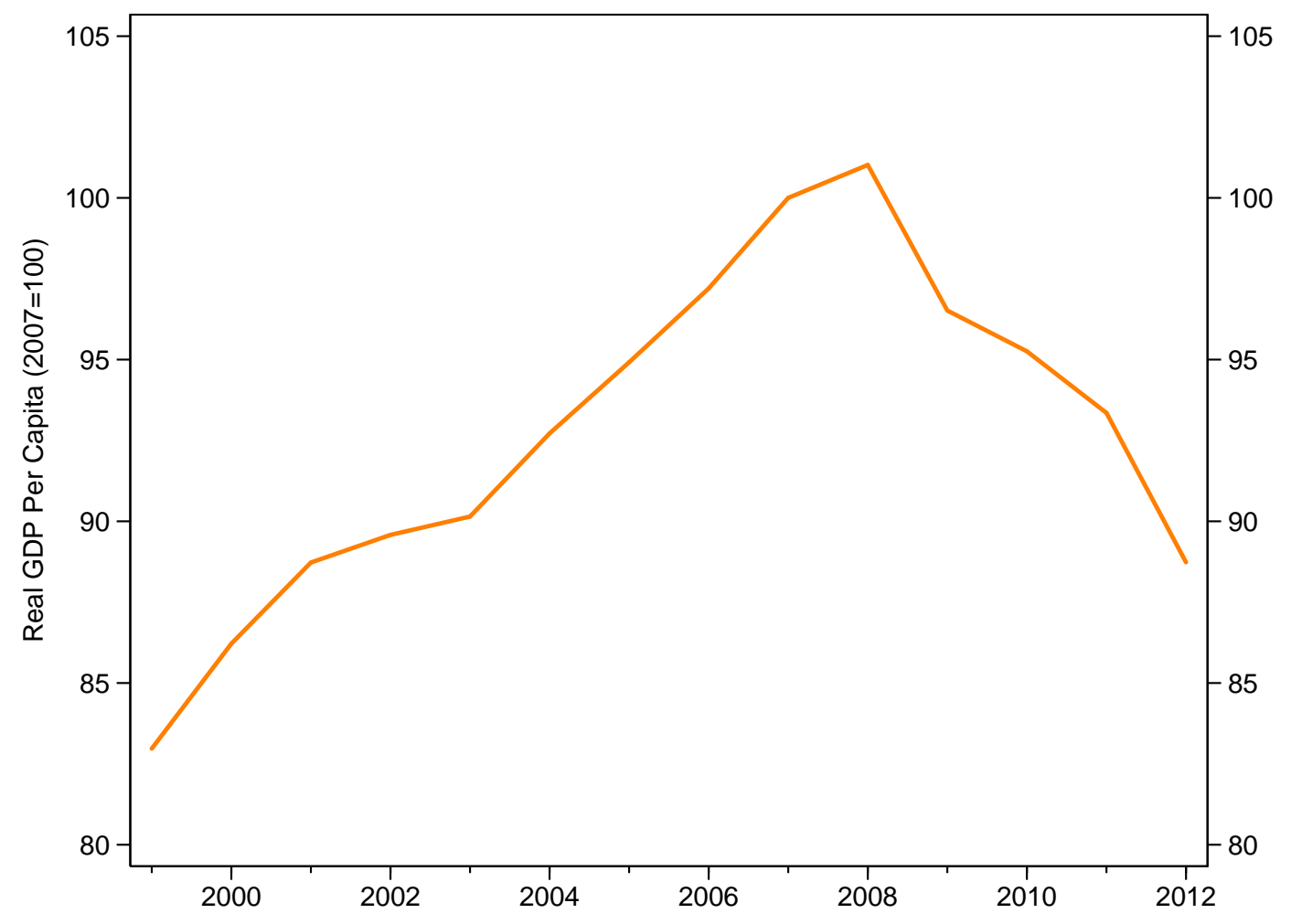




\section{IMFS WORKING PAPER SERIES}

\section{Recent Issues}

$\begin{array}{ll}\mathbf{7 8} / \mathbf{2 0 1 4} & \begin{array}{l}\text { Michael Binder } \\ \text { Marcel Bluhm }\end{array} \\ \mathbf{7 7} / \mathbf{2 0 1 4} & \text { Helmut Siekmann } \\ \mathbf{7 6 ~ / ~ 2 0 1 3} & \text { Y. Emily Yoo }\end{array}$

On the Conditional Effects of IMF Loan Program Participation on Output Growth

Zur Offenlegung der Bezüge von Sparkassenführungskräften im Internet

Financial Regulation and Supervision Across Business Lines in the United States - Financial Holding Companies post Gramm-Leach-Bliley Act

$75 / 2013$

$74 / 2013$

$73 / 2013$

72 / 2013

$71 / 2013$

$70 / 2013$

69 / 2013

$68 / 2013$

67 / 2012

$66 / 2012$
Athanasios Orphanides

Tilman Bletzinger

Volker Wieland

Tobias H. Tröger

Matthias Burgert

Sebastian Schmidt

Helmut Siekmann

Volker Wieland

Elena Afanasyeva

Tobias H. Tröger

John F. Cogan

John B. Taylor

Volker Wieland

Maik Wolters

Otmar Issing

Volker Wieland

John B. Taylor

Volker Wieland
Is Monetary Policy Overburdened?

Estimating the European Central Bank's

"Extended Period of Time"

The Single Supervisory Mechanism -

Panacea or Quack Banking Regulation?

Dealing with a Liquidity Trap when

Government Debt Matters:

Optimal Time-Consistent Monetary and Fiscal Policy

The European Central Bank's Outright Monetary Transactions and the Federal Constitutional Court of Germany (publ. partially as "The question before the court", in: Economist, June 18, 2013)

Atypical Behavior of Credit:

Evidence from a Monetary VAR

Konzernverantwortung in der aufsichtsunterworfenen Finanzbranche (publ. in: ZHR 2013, S. 475-517)

Fiscal Consolidation Strategy: An Update for the Budget Reform Proposal of March 2013

Monetary Theory and Monetary Policy: Reflections on the Development over the last 150 Years

Surprising Comparative Properties of Monetary Models: Results from a new Model Database 
Missachtung rechtlicher Vorgaben des AEUV durch die Mitgliedstaaten und die EZB in der Schuldenkrise (publ. in: Thomas M.J. Möller und FranzChristoph Zeitler (editors), Europa als Rechtsgemeinschaft - Währungsunion und Schuldenkrise, Tübingen, 2013, pp. 97154)

64 / 2012 Helmut Siekmann

Die Legende von der verfassungsrechtlichen Sonderstellung des „anonymen" Kapitaleigentums (publ. in: Der grundrechtsgeprägte Verfassungsstaat, Festschrift für Klaus Stern zum 80. Geburtstag, herausgegeben von Michael Sachs und Helmut Siekmann, Berlin, 2012, pp. 1527-1541)

$63 / 2012$

Guenter W. Beck

On the Importance of Sectoral and Kirstin Hubrich Massimiliano Marcellino Regional Shocks for Price Setting

62 / 2012 Volker Wieland Maik H. Wolters

Forecasting and Policy Making

$61 / 2012$

John F. Cogan John B. Taylor Volker Wieland Maik H. Wolters

Fiscal Consolidation Strategy (publ. in: Journal of Economic Dynamics and Control, Vol. 37 Issue 2 (February), pp. 404-21)

60 / $2012 \quad$ Peter Tillmann Maik H. Wolters

The Changing Dynamics of US Inflation Persistence: A Quantile Regression Approach

59 / $2012 \quad$ Maik H. Wolters

Evaluating Point and Density Forecasts of DSGE Models

58 / $2012 \quad$ Peter Tillmann

Capital Inflows and Asset Prices: Evidence from Emerging Asia

57 / 2012 Athanasios Orphanides Volker Wieland

Complexity and Monetary Policy (publ. in: Federal Reserve Bank of St. Louis Review, July/August 2008, 90(4), pp. 307-24)

$56 / 2012$

Fabio Verona Manuel M.F. Martins Inês Drumond

(Un)anticipated Monetary Policy in a DSGE Model with a Shadow Banking System

55 / $2012 \quad$ Fabio Verona

Lumpy Investment in Sticky Information General Equilibrium

54 / $2012 \quad$ Tobias H. Tröger

Organizational Choices of Banks and the Effective Supervision of Transnational Financial Institutions (publ. in: Texas International Law Journal, Vol. 48 no. 2, April 2013) 
